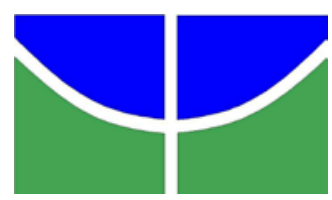

UNIVERSIDADE DE BRASÍLIA

FACULDADE DE CIÊNCIAS DA SAÚDE

PROGRAMA DE PÓS-GRADUAÇÃO EM SAÚDE COLETIVA

PROGRAMA DE INCLUSÃO DIGITAL DOS CONSELHEIROS DE SAÚDE: O USO DAS TECNOLOGIAS DE INFORMAÇÃO E COMUNICAÇÃO AUXILIAM NO CONTROLE SOCIAL?

João Paulo Fernandes da Silva 


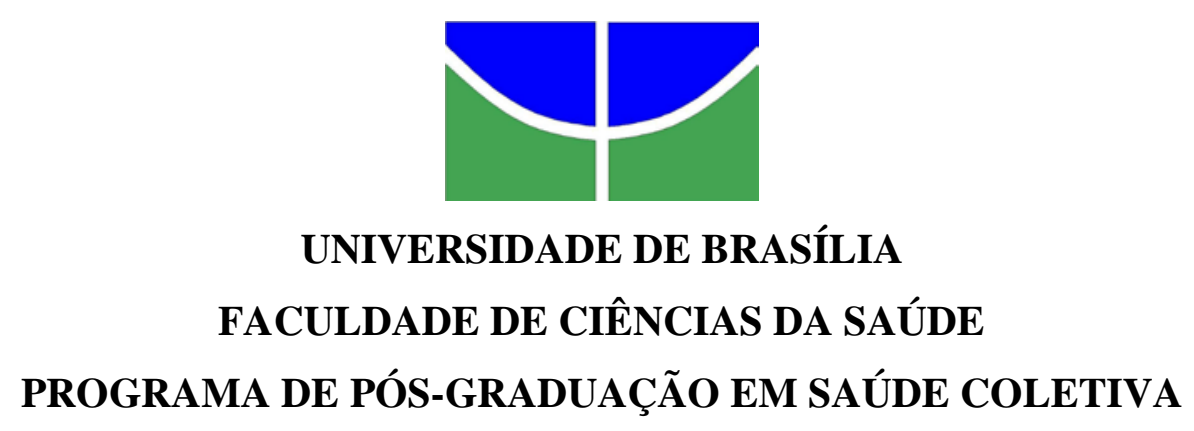

\section{PROGRAMA DE INCLUSÃO DIGITAL DOS CONSELHEIROS DE SAÚDE: O USO DAS TECNOLOGIAS DE INFORMAÇÃO E COMUNICAÇÃO AUXILIAM NO CONTROLE SOCIAL?}

João Paulo Fernandes da Silva

Dissertação apresentada ao Programa de Pós-Graduação em Saúde Coletiva da Universidade de Brasília, como requisito à obtenção do título de Mestre em Saúde Coletiva, área de concentração Saúde, Cultura e Cidadania.

ORIENTADORA: Prof. ${ }^{a}$ Dra. Ana Valéria Machado Mendonça

Brasília, março de 2016 


\section{$\varnothing$ \\ UNIVERSIDADE DE BRASÍLIA \\ FACULDADE DE CIÊNCIAS DA SAÚDE \\ PROGRAMA DE PÓS-GRADUAÇÃO EM SAÚDE COLETIVA}

\section{BANCA EXAMINADORA:}

Prof. ${ }^{a}$ Dra. Ana Valéria Machado Mendonça - Presidente Universidade de Brasília - UnB

Prof. a Dra. Maria Fátima de Sousa - Membro Titular Universidade de Brasília - UnB

Prof. Dr. Jorge Otávio Maia Barreto - Membro Titular Universidade de Brasília - UnB

Prof. ${ }^{a}$ Dra. Maria Célia Delduque - Membro Suplente Universidade de Brasília - UnB 
Dedico este trabalho aos meus pais, minhas filhas Ana Lívia e Maria Eduarda, minha esposa e minha orientadora. 


\section{AGRADECIMENTOS}

Ao meu Deus pelo cuidado, amor e carinho que tens por mim. Só em Ti tenho forças pra lutar.

Aos meus pais, José Geraldo e Antônia Maria, pelos ensinamentos essenciais responsáveis pela formação de meu caráter e personalidade. A vocês devo a vida.

A minha esposa Vanessa Kelly que nos últimos 11 anos esteve ao meu lado, nas dificuldades e alegrias, sempre me apoiando. Você sabe o quanto foram difíceis para mim os últimos 18 meses.

As minha filhas Ana Lívia e Maria Eduarda, por serem tudo para mim e é por elas que busco sempre o melhor, ser um exemplo.

A minha orientadora Valéria Mendonça por acreditar e reconhecer meu potencial. Obrigado por todas as oportunidades.

Aos colegas e amigos do Núcleo de Estudos de Saúde Pública e da Faculdade de Saúde pelas experiências, vivencias e saberes trocados.

E um agradecimento especial a duas grandes amigas, Fabiana Ganem e Elizabeth Prado pela ajuda neste trabalho, desde a concepção do projeto até a análise dos dados. Isto não se tornaria realidade sem a ajuda de vocês. Gratidão eterna. 
"Eu acredito que, as vezes, são as pessoas que ninguém espera nada que fazem as coisas que ninguém consegue imaginar."

Alan Turing 


\section{RESUMO}

Este trabalho teve o Programa de Inclusão Digital do Conselheiros de Saúde (PID/CNS) como ponto de partida para um estudo qualiquantitativo com o objetivo de analisar a contribuição do PID no que tange a apropriação do uso de tecnologias de informação e comunicação para o controle social. Foi desenvolvida no período de março a setembro de 2015 junto aos conselheiros estaduais de saúde de todo o pais. Para a coleta de dados, foi aplicado um questionário de análise da implementação do programa, cujos dados quantitativos foram analisados a partir do uso do software Microsoft Excel, e ainda foram identificadas questões qualitativas, estas analisadas pelo método do Discurso do Sujeito Coletivo, utilizando o software Qualiquantisoft. Ao final, apurou-se o que pensam os conselheiros sobre TIC como estratégia de fortalecimento do controle social, o nível de apropriação e uso de tecnologias e as contribuições do PID, no âmbito de suas etapas, para o exercício do controle social. O estudo nos mostra a importância de programas como o PID tem nos processos de inclusão social, porém, evidenciando de acordo com a percepção dos entrevistados, falhas em seu método de implementação. Também apresenta o perfil dos conselheiros quanto a acesso e posse bem como suas capacidades no uso das TIC.

Palavras-chave: Conselhos de Saúde; Participação Social; Tecnologia da Informação; Comunicação em Saúde; Gestão da Informação; Sistema Único de Saúde. 


\begin{abstract}
This work was the Digital Inclusion Program of Health Councils (PID/CNS) as a starting point for a quantitative and qualitative study aiming to analyze the PID contribution regarding the appropriation of the use of information and communication technologies to control social. It was developed in the period from March to September 2015 with the state board of health across the country. To collect data, we applied an analytical survey of program implementation, whose quantitative data were analyzed from the use of Microsoft Excel software, and qualitative issues were also identified, they analyzed the Collective Subject Discourse method using the Qualiquantisoft software. At the end, it was found that the directors think about ICT as a strengthening strategy of social control, the level of ownership and use of technology and PID contributions within their steps to the exercise of social control. The study shows us the importance of programs such as PID has the social inclusion process, however, showing according to the perception of respondents, failures in its implementation method. It also shows the profile of directors as the access and ownership as well as their skills in using

ICT.
\end{abstract}

Keywords: Health Councils; Social participation; Information Technology; Health Communication; Information management; Health Unic System 


\section{LISTA DE GRÁFICOS}

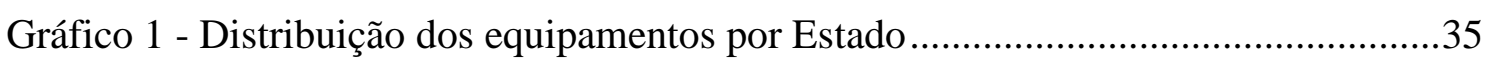

Gráfico 2 - Atividades em TIC que se sentem aptos a realizar .....................................37

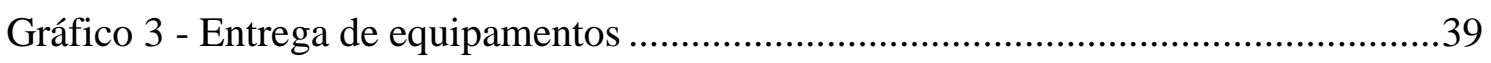

Gráfico 4 - Como os conselheiros qualificam os equipamentos recebidos .....................40

Gráfico 5 - Percepção dos entrevistados que realizaram o curso de formação do

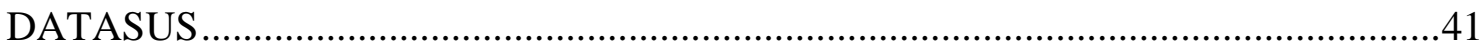




\section{LISTA DE TABELAS}

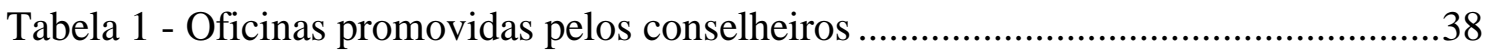

Tabela 2 - Uso dos equipamentos no cotidiano dos conselheiros ...................................39

Tabela 3 - Motivos pelos quais os conselheiros não participaram do curso do

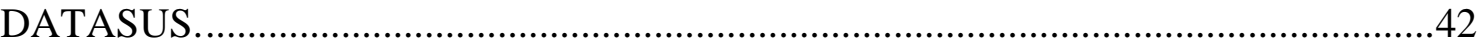




\section{LISTA DE ABREVIATURAS E SIGLAS}

CNS - Conselho Nacional de Saúde

CONDISIS - Conselhos de Saúde Indígenas

COSEMS - Conselhos de Secretarias Municipais de Saúde

DAGEP - Departamento de Apoio à Gestão Estratégica

MS - Ministério da Saúde

PID - Programa de Inclusão Digital dos Conselheiros de Saúde

SGEP - Secretaria de Gestão Estratégica e Participativa

SUS - Sistema Único de Saúde

TIC - Tecnologias da Informação e Comunicação

UnB - Universidade de Brasília 


\section{SUMÁRIO}

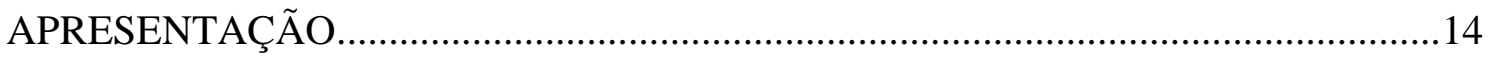

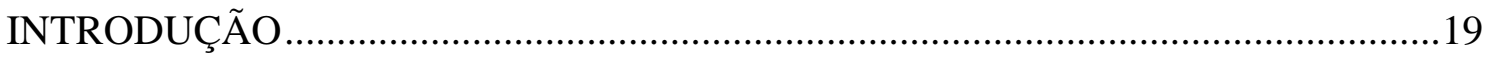

CONTEXTOS DO ESTUDO - O PID EM EVIDÊNCIA ...........................................24

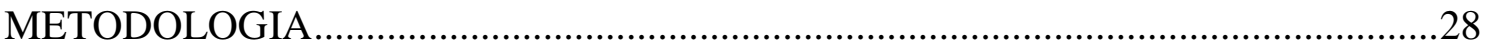

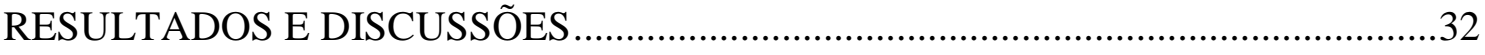

I. TIC COMO ESTRATÉGIA DE FORTALECIMENTO DO CONTROLE SOCIAL

II. ESTÁGIO DA IMPLEMENTAÇÃO DO PROGRAMA DE INCLUSÃO 32

DIGITAL (PID) DE ACORDO COM OS CONSELHEIROS ENTREVISTADOS. 34

III. FORMAÇÃO E ASPECTOS SOCIAIS E HUMANOS...................................... 41

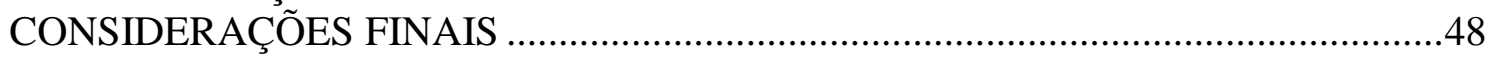

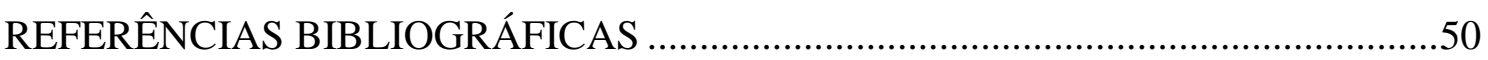

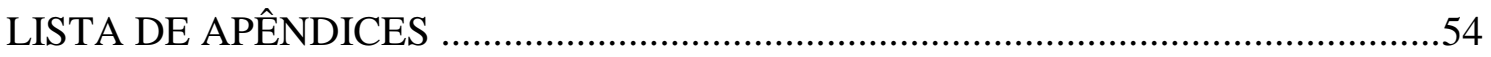




\section{APRESENTAÇÃO}

O passeio que mais gostava quando garoto era visitar lojas e centros comerciais para apreciar e conhecer, nem que fosse só de vista, novidades tecnológicas. Sonhava diante de uma vitrine, e não achando suficiente apenas namorar os equipamentos, fazia verdadeiros interrogatórios com os vendedores ou representantes nos estabelecimentos, que após algumas perguntas, mudavam o semblante. Até hoje não sei se isso se dava por ficarem admirados como um garoto poderia questionar tanto ou se achavam que eu seria só mais um projeto de possível comprador amolador, que após tomar-lhes tanto tempo com indagações, iria apenas agradecer as informações e sair sem levar nada.

Na época, início da década de 90, eu era apenas mais um jovem pobre de uma cidade satélite de Ceilândia, periferia do Distrito Federal, onde moro até hoje. Meu pai, José Geraldo, mais conhecido por "Zé Lambreta", apelido ganho ainda na juventude por ter possuído uma motoneta, era motorista de ônibus e todo o seu recurso financeiro era destinado ao sustento da família e à construção da nossa tão sonhada casa. Minha mãe, Antonia Maria, conhecida por "Toinha", complementava a renda com sua atividade de costureira, e logo passou a vender roupas e cosméticos em casa, atividade que mantém até hoje; por sua vez, ainda cuidava dos três filhos, eu, minha irmã Ana Lúcia e meu irmão Paulo César, o "Pira".

Tendo consciência de minha condição financeira, logo pensei em uma forma de conseguir meu próprio dinheiro, tirando proveito do fascínio que tenho por eletroeletrônicos que perpassava a admiração visual e teórica; eu não sossegava enquanto não entendesse como aquilo funcionava em suas entranhas. Uma curiosidade que em pouco tempo me rendera alguns trocados, pois com apenas 13 anos, fiquei conhecido na vizinhança como o mecânico de eletrodomésticos. Não era muito mas já me permitia considerar a aquisição de um dos aparelhos que, até então, eu só sonhava diante um mostruário.

Aos 14 anos, mais exatamente no ano de 1994, fui para uma festa em uma casa em uma região nobre de Brasília, onde acabei ficando muito amigo do filho da família. Ele possuía um computador com processador Intel i386 (digna peça de museu da atualidade) que me deixou deslumbrado, atônito e curioso, afinal, até onde eu tinha conhecimento, computador era algo para uso apenas em empresas, indústrias, para quê alguém teria um computador em casa? Tão logo o garoto dono do computador o colocou em funcionamento, e a medida em que ele "mexia", um sentimento de 
frustração tomava conta de mim. Só para jogos que isso serve? Algo que qualquer videogame da época faria sem toda aquela complicação de digitar linhas de códigos.

Meu primeiro contato com computadores não foi algo tão fantástico como eu imaginava, alimentado por uma expectativa de um equipamento que, segundo noticiavam as mídias de massa, seria a revolução nos meios de comunicação. No Brasil, Internet era algo pouco conhecido, um serviço desfrutado apenas por universidades, instituições de pesquisa e órgãos do governo. Logo, ter um computador nessa época não era algo tão útil, divertido e interessante como hoje, ao menos para o usuário doméstico.

Em maio de 1995, a Internet é liberada para comercialização pela portaria no. 148 de 31 de maio de 1995 (DOU 145, 1995) que aprovara a norma no. 004/95 que por sua vez tinha o objetivo de regular o uso da rede pública de comunicação para conexão de internet. Porém, ainda não foi dessa forma que os brasileiros conheceram a internet. Assim como a telefonia celular, Internet era um serviço caro e não muito popular. Foi em novembro deste mesmo ano, através de uma telenovela de nome Explode Coração transmitida pela Rede Globo, que ficou conhecida esta que viria a ser a revolução das telecomunicações. Que tecnologia é essa que permite pessoas se comunicam por mensagens e trocar imagens através de um computador?

Em 1996, agora com 16 anos e cursando o ensino médio, recebi um folheto na porta da escola. Lá informavam sobre alguns cursos de capacitação profissional financiados com recursos do Fundo de Amparo ao Trabalhador (FAT) e ofertados pelo governo do Distrito Federal. Um dos cursos, em especial, me chamou muito a atenção, "Auxiliar de escritório". Não por atividades desenvolvidas ou mesmo afinidade, o que me interessava na ementa do curso eram as "noções de internet". Cursos de informática eram muito caros e os ofertados pelo governo eram bastante concorridos. Vi nesse curso a grande oportunidade de, finalmente, conhecer essa tal novidade. O curso teve apenas duas semanas de duração e só no penúltimo dia, uma quinta feira, por exatas duas horas, experimentei esta tecnologia. Não pude fazer muito, afinal, não conhecia os "macetes" da navegação e tinha que me manter atento às orientações do professor. Foi pouco o tempo mas o suficiente para me deixar encantado e apaixonado.

Um ano depois, em meu aniversário de 17 anos, ganhei de presente de minha mãe, meu primeiro computador. Eu não me cabia de tamanha satisfação. Era um Intel Pentium 133Mhz MMX, com 32 Megas de memória RAM e disco rígido de 1.7 Gigabits. Mas, como todo brinquedo novo vai perdendo a graça, o computador foi ficando desinteressante. Já não conseguia encontrar algo novo para fazer e internet era 
algo difícil, ainda que eu conseguisse me conectar, sempre arrumava uma confusão com minha mãe por conta da linha telefônica que ficava ocupada e pelos altos valores das faturas. Precisei mudar a estratégia, passei a me conectar durante a madrugada sem que minha mãe soubesse. A partir de então, o computador passou a ter um outro sentido, horas foram gastas com muita leitura, conversas e diversão virtual.

Apenas em 2001 fiz o meu primeiro curso de informática. Ao final, pedi demissão da empresa de segurança onde trabalhava e fui para uma grande empresa de informática de Brasília, NOVADATA. Trabalhei por quatro anos na manutenção de computadores e, já com experiência no ofício, no início de 2006 me desliguei. Coincidentemente, neste mesmo ano, recebi uma proposta de realizar a manutenção dos computadores que compunham o parque tecnológico do Núcleo de Estudos de Saúde Pública (NESP). Após a realização do serviço, recebi um convite, desta vez para me integrar a equipe do Núcleo, junto à Unidade de Tecnologia de Informação e Comunição em Saúde (UTICS), coordenado pela então doutoranda Ana Valéria Machado Mendonça. Era 6 de junho de 2006, mais precisamente às 18 horas, na cerimônia de inauguração da UTICS, que se deu início ao vínculo profissional e acadêmico que viria a ter com o NESP e a Universidade de Brasília - UnB e que perdura até os dias de hoje.

Com experiências de outrora, logo já não havia o que fazer no que dizia respeito à manutenção de equipamentos do NESP, foi quando passei a apoiar os projetos de pesquisas com desenvolvimento de máscaras em Epi Info para coleta e análise de dados. Começava então um nova fase em minha vida profissional, percebi que poderia ser mais que um simples mecânico de computadores.

Em 2008, já com dois anos de NESP e alguns trabalhos de apoio à pesquisa realizados, fui convidado para fazer parte da equipe do Projeto de Inclusão Digital dos Agentes Comunitários de Saúde do Distrito Federal e Sergipe. O projeto coordenado pela Profa. Valéria Mendonça (coordenadora da UTICS), e que seguia o modelo do Programa Governo Eletrônico - Serviço de Atendimento ao Cidadão (GESAC) que tem o objetivo de promover a inclusão digital através de uma plataforma em rede, serviços e aplicações ofertando instrumentos de TIC e capacitação. Assim como o GESAC, o projeto de inclusão digital dos ACS também previa a oferta de recursos de TIC, capacitação dos agentes e uma plataforma de ensino a distância para educação continuada. 
O desafio que assumi no projeto, inicialmente, foi o de capacitar o multiplicadores. Após o período de capacitação, assumi a função de supervisão dos Centros de Atendimento Tecnológico de Informação e Informática em Saúde (CATIS) do DF, assim eram chamados os laboratórios de informática montados em sete cidades satélites do Distrito Federal (Brazlândia, Ceilândia, Itapoã, Paranoá, Recanto das Emas, Samambaia e Faculdade de Saúde-UnB) e cinco municípios de Sergipe (Aracaju, Itabaiana, Lagarto, Propriá e Tobias Barreto). Ao final do projeto, iniciou-se um segundo com o mesmo propósito, porém, contemplando apenas o DF e três municípios do entorno (Águas Lindas, Valparaíso de Goiás e Planaltina de Goiás), que compõem a Região de Integrada de Desenvolvimento Econômico do DF (RIDE-DF).

Seguindo na linha de programas, projetos e iniciativas de inclusão digital, por coincidência, conheci o Programa de Inclusão Digital dos Conselheiros de Saúde, o PID. O programa resulta de demandas de conferências de saúde, com aprovação do Conselho Nacional de Saúde(CNS) e executado pela Secretaria de Gestão Estratégica e Participativa (SGEP) do Ministério da Saúde, tem por objetivo contribuir para que conselheiros de saúde nas três esferas se apropriem de informações e habilidades na área da comunicação para o exercício do controle social, por intermédio de equipamentos de informática e informação em saúde. Por se tratar de um programa em âmbito nacional, aguçou-me a vontade de entender como labora algo de tamanha dimensão. Não demorou muito, fiz do programa o meu objeto de pesquisa no projeto e concorri a uma vaga do programa de pós-graduação em Saúde Coletiva da Faculdade de Ciências da Saúde da Universidade de Brasília.

Com a consolidação das tecnologias de informação e comunicação em um aspecto geral, faz-se necessário um estudo sobre o programa, que busque compreender o modelo de implementação e se a forma como fora estruturado em três pilares fundamentais que compreendem equipamentos, formação e conectividade, permite que o PID obtenha êxito em seu objetivo, isso sob o ponto de vista dos conselheiros.

Neste contexto, ressalta-se a necessidade em investigar o acesso dos conselheiros a recursos e serviços de tecnologia e, dentro dessa lógica, evidenciar facilidades e dificuldades no uso para exercício do controle social.

O referencial teórico busca abordar os conceitos, evolução e experiências exitosas de programas de inclusão digital anteriores, bem como surgimento e avanços do controle social. A metodologia delineada nesta pesquisa busca ir ao encontro de hipóteses que afirmem, ou não, a efetividade de iniciativas como o PID no que dedilha 
os objetivos propostos e quanto ao modelo adotado, através de questões objetivas e Discurso do Sujeito Coletivo (DSC).

Os resultados e discussões apresentados evidenciam o que compreendem os conselheiros estaduais de saúde de 24 estados e da, à época, presidente do CNS em relação a iniciativas de inclusão digital e o controle social , tendo como base o PID.

Por fim, considerações finais irão apontar necessidades de continuidade de projetos como o PID, bem como evidenciar falhas e possíveis avanços que permitam a melhora desta que vem ser uma ferramenta não só de fortalecimento do controle social mas também de inclusão social. 


\section{INTRODUÇÃO}

O acesso às Tecnologias da Informação e Comunicação (TIC) tem sido visto como alternativa para melhoria da qualidade de vida e bem estar dos cidadãos, pelo fato de potencializar maior intercâmbio de conhecimentos e experiências entre indivíduos, famílias e comunidades. Isso provocou o surgimento de uma nova ação, denominada inclusão digital. Por sua vez, tratam-se de iniciativas voltadas à promoção do acesso às tecnologias, objetivando tanto facilitar a inserção às novas tecnologias de informação, ainda muito dispendiosas para grande parte da população, quanto, sobretudo, efetivar a possibilidade de utilizá-las (SANTOS e CARDOSO, 2009).

Inclusão Digital, é mais do que um conceito, é uma estratégia utilizada em diferentes locais, grupos ou segmentos com baixa acessibilidade às TIC. Assim, fala-se em exclusão digital quando há uma debilidade de acesso às tecnologias de informação e comunicação, seja no campo da infraestrutura, seja no campo da produção e difusão de conteúdos. Partindo dessa ideia, a inclusão digital passa a ser a estratégia de acesso ao mundo virtual para promover desenvolvimento intelectual, operacional e técnico, ou seja, além do acesso é preciso ter a capacidade de operar com autonomia (PASSERINO, 2007).

Metade dos domicílios brasileiros possuem acesso à Internet, representando 32,3 milhões de domicílios no país. É o que afirma a Pesquisa TIC Domicílios (CGI.br, 2014), desenvolvida pelo Comitê Gestor da Internet no Brasil (CGI.br) e que desde 2005 desenvolve estudos no campo das TIC.

No entanto, apesar dos números animadores, o acesso à informação por meio do uso das TIC permanece como um desafio para a população brasileira. Dados da última pesquisa destacam os 32,7 milhões de domicílios que não possuem acesso à internet. (CGI.br, 2014). O alto custo financeiro deste acesso ainda é a maior justificativa para este elevado índice, que se concentra em áreas urbanas (25,5 milhões), nas classes C (16,5 milhões) e DE (13,2 milhões), e com renda domiciliar abaixo de dois salários mínimos (22,9 milhões)(CGI.br, 2014, p. 135).

Apesar da pouca evolução do cenário, se comparado à mesma pesquisa publicada em 2013, onde, em números brutos, a quantidade de brasileiros excluídos digitalmente com idade superior a nove anos era de 69,9 milhões (CGI.br, 2013, p. 178), e das facilidades e inovações ofertadas pela evolução dos meios e métodos de comunicação, a exemplo dos smartphones, tablets, notebooks, mídias sociais, internet 
móvel, wi-fi e Smart TV's, os problemas da exclusão ainda persistem, associados também à dificuldade de acesso ao uso.

Como tentativa de solucionar o problema de acesso, surgiram no país iniciativas de inclusão digital, a exemplo do Programa Governo Eletrônico Serviço de Atendimento ao Cidadão (GESAC). Estas iniciativas limitavam-se a disponibilizar computadores conectados à internet e, posteriormente, abrangeu as possibilidades de produção e compartilhamento de conteúdos.

Porém, para que isso aconteça é necessário rever a forma de apropriação destes instrumentais tecnológicos de modo que, o seu uso cotidiano, favoreça a participação social, mediada por interações que, estabelecendo diálogos, ressaltem as suas especificidades dentro de um contexto mais complexo, a exemplo dos Conselhos de Saúde. Nesse contexto ideológico nasceram importantes críticas aos projetos de inclusão digital que forneciam hardware e software sem abordar o aspecto educacional, tampouco os sistemas sociais envolvidos (PASSERINO, 2007).

É importante avaliar que, numa sociedade caracterizada ou definida como Sociedade da Informação, em que o avanço tecnológico tem afetado não somente as condições culturais, mas principalmente as relações de trabalho, com a oferta de novos postos de produção e a extinção e tantos outros, estar excluído desse processo por desconhecimento ou não utilização coloca o individuo numa situação de distanciamento (MENDONÇA, 2008).

O Conselho Nacional de Saúde (CNS) é um órgão colegiado de caráter permanente e deliberativo que integra a estrutura regimental do ministério da Saúde. (BRASIL, 1999). Esta determinação foi dada pela Constituição Federal em seu artigo 198 e pelas Leis $n^{\circ} 8.080$ de 19 de setembro de 1990 e $n^{\circ}$ 8.142, de 28 de dezembro de 1990. Composto por representantes do governo, dos prestadores de serviços, dos profissionais de saúde e dos usuários do SUS, tem como missão a deliberação, fiscalização, acompanhamento e monitoramento das políticas públicas de saúde, sendo suas decisões, quando consolidadas em resoluções, são homologadas pelo Ministro de Estado da Saúde (REGIMENTO CNS) (BRASIL, 1990).

No Brasil, o controle social quando visto do campo das políticas sociais, é tratado muitas vezes como sinônimo da participação da sociedade civil nas ações do Estado (BRAVO, 2012), entretanto, a expressão tanto pode ser empregada para designar o controle do Estado sobre a sociedade quanto o controle da sociedade sobre as ações do Estado (VERBENA, 2007) 
A época do seu surgimento, a atual conjuntura política encontrou neste campo um contraponto para que houvesse um processo de redemocratização apresentado pelo Movimento da Reforma Sanitária Brasileira, no seu conjunto de lutas contra a privatização da medicina previdenciária, regulação da saúde pelo mercado, entre outros. Este ambiente de efervescência política forjaram o tema da $8^{\text {a }}$ Conferência Nacional de Saúde que teve como marca a frase Democracia é Saúde (BRAVO, 2012).

Os mecanismos do controle social foram implementados no Brasil a partir dos anos 1990 ainda neste cenário de mudanças sociais.

Conselhos e Conferências de Saúde, atualmente, são os principais espaços para o exercício da participação e do controle social nas três instâncias públicas: municipal, estadual e federal, expressando a correlação de forças existentes no conjunto da sociedade na relação entre o Estado e a Sociedade Civil (BRAVO, 2012).

Por meio dos conselhos de saúde, a população poderia intervir na gestão de políticas públicas, de forma autônoma, na formulação de estratégias e no controle da execução da política de saúde, inclusive nos aspectos econômicos e financeiros. Destaca-se, portanto, que o controle social refere-se às ações para monitorar, fiscalizar, avaliar e intervir na gestão das políticas de saúde, a partir da participação social (BRASIL, 2013).

O processo decisório nos conselhos de saúde está diretamente atrelado a existência de ferramentas que possibilitem a participação democrática, neste sentido, a informação e a comunicação passam a ser elementos estratégicos para o controle social. Neste rol de aparatos que envolvem o processo informação e comunicação em saúde o acesso às informações deve ser amplo suficiente para promover os envolvidos à atores e sujeitos políticos. Democratização do acesso e superação de barreiras e obstáculos à comunicação precisam compor uma ação estratégica no exercício do controle social, afim de fortalecê-lo e pro conseguinte, efetivar o processo de conhecimento sobre o Sistema Único de Saúde, que envolve aspectos da legislação, da realidade epidemiológica, assistencial, financeira, política, entre outras. (VERBENA, 2007)

O conceito de informação pode ser simplificado como o conhecimento comunicado ou, a comunicação do conhecimento, e possui um papel central na sociedade contemporânea. É considerada condição básica do desenvolvimento econômico e social, e com o surgimento da tecnologia da informação assume uma aspecto significativo pela sua natureza digital. (CAPURRO, 2007). 
Na área de saúde coletiva, a comunicação em saúde diz respeito ao estudo, formulação e utilização de estratégias de comunicação para informar e pode subsidiar as decisões para políticas públicas e promoção da saúde. De fato, a prática da comunicação em saúde é global o suficiente para transversalizar estrategicamente todas as áreas da saúde, embora seja, por si, uma área de estudo importante, podendo ser contextualizada. (VERBENA, 2007)

A incorporação da tecnologia de informação e comunicação nos processos participativos da gestão, favorecem o desenvolvimento da prática reflexiva, da capacidade crítica, da compreensão de que cada indivíduo produz conhecimento, bem como a valorização do ser humano em sua multidimensionalidade e a compreensão de que todos podem se tornar agentes de mudança. (ALMEIDA, 2003).

A participação e o controle social em saúde têm grande relevância dentre os princípios do SUS, constituindo como parte do processo histórico de formulação e controle das políticas públicas de saúde e garantindo a participação da comunidade nos processos decisórios sobre políticas públicas e ao controle sobre a ação do Estado (ARANTES et al., 2007).

Mark Warschauer em sua obra Tecnologia e Inclusão Social, destaca a importância dos projetos que se utilizam das TIC para a economia, desenvolvimento social por meio do acesso ao conhecimento, destacando que os recursos físicos, humanos, sociais e digitais devem compor uma estrutura que favoreça a geração do conhecimento. E nas perspectiva da inclusão social as iniciativas de inclusão digital devem ser abertas à inovação e flexíveis às realidades locais. (WARSCHAUER, 2006)

Nesse cenário nacional de iniciativas de inclusão das TIC na rotina do cidadão, surgiu o Programa de Inclusão Digital do Conselho Nacional de Saúde (PID/CNS). Assim, o PID foi idealizado com o objetivo de incorporar o uso da informática e da internet como ferramentas para busca de informações em saúde e para o reforço à comunicação entre conselhos e dessas instâncias com a sociedade.

Esta pesquisa se debruçou sobre este programa, a análise do processo de inclusão digital idealizado para ocorrer junto aos Conselheiros de Saúde e os efeitos deste processo no âmbito controle social, tendo como objetivo geral analisar a contribuição do Programa de Inclusão Digital dos Conselheiros de Saúde no que tange a apropriação do uso de tecnologias de informação e comunicação para o controle social.

Com o presente estudo espera-se ainda enquanto objetivos específicos conhecer o modelo de implantação do PID; descrever o cenário atual de uso das TIC nos 
Conselhos de Saúde; e investigar, junto aos conselheiros, a percepção destes frente ao uso das TIC no controle social.

Sua execução fez-se necessária pelos objetivos que apresenta o PID, no que toca à melhoria da comunicação e da gestão da informação entre os entes federados e o fortalecimento dos conselheiros na participação e controle social. Assim, acompanhando os avanços tecnológicos que podem aprimorar o processo de conhecimento à distância ou semipresencial destes profissionais da saúde, e de possibilitar à sociedade, o acesso à informação e à comunicação nas questões de saúde pública, um estudo sobre o PID também pode vir a auxiliar os processos de cuidar da saúde, melhorando a qualidade de suas vidas. 


\section{CONTEXTOS DO ESTUDO - O PID EM EVIDÊNCIA}

O PID está presente no $2^{\circ}$ Plano de Ação Brasileiro como um dos seis compromissos assumidos pelo Ministério da Saúde. A sua meta baseia-se na entrega de equipamentos, conexão e formação dos conselheiros de saúde para uso das tecnologias, de forma a contribuir com o exercício do controle social no SUS. O compromisso do Programa de Inclusão Digital dos Conselhos de Saúde está disponível no portal governoaberto.cgu.br.

O programa surgiu como demanda apresentada na $12^{\text {a }}$ Conferência Nacional de Saúde, sob o tema “Informação e Comunicação em Saúde”, onde levantou-se a necessidade do CNS traçar estratégias para deliberação e implementação de políticas articuladas de informação e comunicação no sentido de ampliar a participação e o controle social, observando a proposta de democratização da informação, viabilidade de uma rede de informação nacional e projetos que garantissem a divulgação permanente para a população das decisões e informações dos conselhos e conferências de saúde (BRASIL, 2004)(CARVALHO, 2009).

Em seguimento à proposta apresentada na $12^{\mathrm{a}}$ Conferência Nacional de Saúde, o Conselho Nacional de Saúde, no âmbito do Pacto pela Democratização e Qualidade da Comunicação e Informação em Saúde, foram realizados seis seminários cujo objetivo era discutir a Política de Comunicação, Informação e Informática em Saúde, a reativação da Comissão Intersetorial de Comunicação e Informação em Saúde (CICIS) e, entre outros temas, a implantação de um projeto de inclusão digital para os conselheiros de saúde (CARVALHO, 2009)

Embasado nas propostas apresentadas nos Seminários Regionais e Nacional de Comunicação, Informação e Informática em Saúde, realizados nos anos de 2005 e 2006, o relatório final imprime a diretriz fortalecer a ação pública no campo informacional para o apoio a atuação dos conselhos de saúde e dos órgãos de controle interno e externo e aponta seguintes necessidades (BRASIL 2006):

- Considerar a comunicação e informação como questão estratégica, destinando recursos para aquisição de equipamentos e capacitação dos profissionais;

- Criar uma rede de comunicação interligada em nível nacional entre os conselhos de saúde; 
- Garantir a formação dos conselheiros de saúde em informática, controle social, comunicação e informação em saúde, possibilitando o acesso às informações do SUS

- $\quad$ Garantir o acesso da população aos equipamentos de informática;

- Garantir conectividade aos equipamentos de informática pertencentes aos conselhos de saúde;

- $\quad$ Fazer a opção pelo uso de software livre no processo de informatização do SUS.

A partir deste cenário, o PID então passa a ser uma iniciativa da Comissão Intersetorial de Comunicação e Informação em Saúde (CICIS) do Conselho Nacional de Saúde (CNS), em parceria com o Departamento de Gestão Participativa do Ministério da Saúde (DAGEP/SGEP/MS). Coube a Secretaria de Gestão Estratégica e Participativa (SGEP), em cumprimento a sua meta institucional de fortalecimento e apoio aos Conselhos de Saúde (CARVALHO, 2009).

Inicialmente, as ações do Programa de Inclusão Digital foram desenvolvidas em parceria pelo CNS, SGEP/MS, Fiocruz e Banco do Brasil. A meta era atender, gradativamente, até 2009, todos os conselhos cadastrados no Cadastro Nacional de Conselhos de Saúde. A proposta inicial do PID se deu no âmbito das discussões do "Pacto pela Democratização e Qualidade da Comunicação, Informação e Informática em Saúde", cujo objetivo é incorporar as TIC ao cotidiano dos conselhos de saúde, qualificando o controle social no Sistema Único de Saúde (SUS). Neste sentido, o PID passa a ser um instrumento para promover a participação e controle social por meio da comunicação em saúde, com o argumento de que para a melhoria das Políticas Públicas de Saúde e o aprimoramento do SUS é necessário que indivíduos e coletivos possam intervir.

Entende-se, portanto, como o objetivo do PID promover, por meio das TIC, a qualificação do controle social, a transparência para a sociedade, o acesso às informações e uma ruptura, onde o papel de expectador torna-se obsoleto em função da participação. Segundo afirma o documento orientador do Programa,

A geração de conhecimento aliado ao controle social, possibilita ganhos de eficiência e qualidade mensuráveis por meio da ampliação de acesso, equidade, integralidade e humanização dos serviços, contribuindo para a melhoria da situação de saúde da população (DAGEP/MS). 
O PID está estruturado em três componentes básicos: equipamentos, conectividade e formação dos conselheiros, e teve sua execução planejada através de etapas distintas. A previsão era que seu início fosse no segundo semestre de 2006 e seu encerramento em junho de 2009. As etapas planejadas estão descritas a seguir:

Etapa 1 - consolidação de parcerias para distribuição de computadores, implantação de acesso à internet e elaboração de conteúdo programático para a formação;

Etapa 2 - implantação do projeto-piloto em sete municípios e três estados, dois em cada região brasileira;

Etapa 3 - avaliação do projeto-piloto e reestruturação para aplicação em larga escala;

Etapa 4 - estabelecimento de aplicativos para trabalho em rede (ex: videoconferência, sítios da internet, e-mails, chats, fóruns e outros);

Etapa 5 - implantação do projeto em nível nacional;

Etapa 6 - implantação do observatório de problemas de saúde para o controle social;

Etapa 7 - desenvolvimento de indicadores e processos de monitoramento e avaliação.

O processo de monitoramento e avaliação do Programa foi pautado em uma série de critérios que constituem avanços significativos no processo de fortalecimento dos conselhos:

1. Reafirmação da importância dos conselhos;

2. Organização de rede de articulação entre os diversos atores inseridos na ação de fortalecimento dos conselhos;

3. Ampliação das condições de funcionamento dos conselhos;

4. Resgate do papel fundamental de cada representante do Grupo de Acompanhamento e Monitoramento do Programa - GT PID dos estados.

5. Apropriação de informações e conhecimentos para intervenção qualificada em defesa do SUS pelos conselheiros;

6. Promoção de iniciativas de comunicação e informação descentralizadas e organizadas em rede para divulgar experiências locais,

7. Fortalecimento da participação e controle social. 
Entretanto, não existem registros sobre o acompanhamento e monitoramento dos cursos, seja nos aspectos relacionados ao conteúdo, seja na quantidade de conselheiros atendidos nas formações.

Em relação ao eixo formação para os conselheiros de saúde, foram propostos dois módulos:

\section{Módulo I - Curso de Informática para Conselheiros de Saúde -} realizado pelo Departamento de Informática do SUS (DATASUS), desenvolvido para os conselheiros estaduais e municipais de saúde, prioritariamente inseridos no PID, por meio das equipes dos DATASUS Regionais nos estados, em articulação com os Conselhos Estaduais de Saúde e os Grupos de Acompanhamento do PID dos estados

\section{Módulo II- Informação e Comunicação em Saúde para o Controle}

Social - realizado por meio de um convênio entre a SGEP/MS em articulação com o Conselho Nacional de Saúde, com a ENSP- Fiocruz.

Dessa forma o PID foi estruturado e posto em execução, porem, contrariando o planejamento inicial, não se encerrou no ano 2009 e ainda se encontra em efetivação. Para o melhor entendimento dos resultados, é necessário compreender os métodos de coleta e análise utilizados e serão apresentados a seguir. 


\section{METODOLOGIA}

Esta pesquisa se desenvolveu ao longo dos seus 18 meses de execução, a partir da abordagem qualiquantitativa, à luz de Minayo e Sanches (1993), que nos possibilitam o entendimento da junção entre os dois procedimentos metodológicos e que nos levam ao conjunto de métodos e técnicas utilizados para o alcance dos objetivos propostos.

Possibilita-nos ainda descrever, compreender e explicar nosso objeto de estudo a saber: o uso das tecnologias de informação e comunicação para o controle social no Sistema Único de Saúde (SUS). Embora não possamos garantir a profundidade requerida por alguns estudos da mesma área, dedicamo-nos a decifrar alguns achados numéricos, associados às entrevistas realizadas com os conselheiros de saúde de 26 unidades da Federação selecionados de forma aleatória e, em alguns casos, indicados pelas secretarias dos conselhos. Apenas uma unidade federada não compareceu em cinco momentos da pesquisa agendados com antecedência.

A revisão de literatura permitiu-nos o aprofundamento bibliográfico no que tange à inclusão social e digital, bem como ao uso das TIC no controle social do SUS pelos conselheiros de saúde nos estados. A análise dos dados quantitativos foi realizada com uso do software Microsoft Excel enquanto a análise qualitativa utilizou-se do Qualiquantisoft para apreciação dos discursos coletivos dos entrevistados.

\section{O discurso do sujeito coletivo como técnica de análise}

A técnica de análise do Discurso do Sujeito Coletivo (DSC) nos apresenta os achados de pesquisas qualitativas por intermédio da expressão do pensamento de um coletivo de sujeitos de pesquisa. Desse modo, estes sujeitos se tornam um único entrevistado, e as múltiplas falas, por sua vez, apresentam-se num discurso de igual maneira único. Para compreendermos melhor a estratégia desenvolvida por seus autores, vejamos:

O DSC como técnica consiste em uma série de operações sobre a matériaprima dos depoimentos individuais ou de outro tipo de material verbal (artigos de jornais, revistas, discussões em grupo etc.), operações que redundam, ao final do processo, em depoimentos coletivos, ou seja, constructos confeccionados com estratos literais do conteúdo mais significativo dos diferentes depoimentos que apresentam sentidos semelhantes. (LEFÈVRE e LEFÈVRE, 2010, p. 17). 
De acordo com Lefèvre e Lefèvre (2003), a metodologia possibilita o resgate do sentido das opiniões do coletivo de entrevistados, para esta pesquisa, os conselheiros de saúde, e a partir deste sentido singular formar os DSCs, constituindo assim um processo que deve ser efetuado por um conjunto de etapas realizadas sobre o material coletado. São elas:

- Expressões-Chave (E-Ch), partes selecionadas de cada entrevista/depoimento dos conselheiros entrevistados, e que descrevem o conteúdo da melhor maneira.

- Ideias Centrais (ICs) fórmulas que descrevem os sentidos presentes nas entrevistas/depoimentos; estes por sua vez podem ser individuais ou no coletivo dos depoimentos, e que apresentam sentido semelhante ou complementar.

- Ancoragens (ACs), também são fórmulas que descrevem as ideologias, os valores e as crenças identificadas nos depoimentos, individuais ou no coletivo dos depoimentos, na forma de afirmações genéricas destinadas a situar situações particulares citadas pelos entrevistados. Conforme a proposta metodológica, somente quando os depoimentos apresentam marcas discursivas dessas afirmações genéricas, existirão ACs.

- Discursos do Sujeito Coletivo (DSCs), reúnem as E-Ch encontradas nas entrevistas/depoimentos, e que possuem ICs e/ou ACs com sentido semelhante ou complementar.

Esta técnica também nos remete à seleção de uma "Expressão-Chave”, que são os trechos mais representativos das respostas dos entrevistados para cada questão de pesquisa. Cada uma destas Expressões terá uma Ideia Central correspondente, que terá seu discurso sintetizado. Com este material podemos construir o discurso-síntese, que são os DSCs propriamente ditos, em resumo: o pensamento coletivo extraído de entrevistas/depoimentos individuais, cujo texto será elaborado na primeira pessoa do singular. Resumidamente, o Instituto de Pesquisa do Discurso do Sujeito Coletivo apresenta (2015):

O Discurso do Sujeito Coletivo ou DSC é isso: um discurso síntese elaborado com pedaços de discursos de sentido semelhante reunidos num só discurso. ... Em uma palavra, o DSC constitui uma técnica de pesquisa qualitativa criada para fazer uma coletividade falar, como se fosse um só indivíduo. (IPDSC, 2015). 
Lefèvre e Lefèvre (2005) anunciam que a técnica consiste na análise do material coletado em pesquisas que possuam entrevistas/depoimentos como "matéria prima". Assim, é possível extrair de cada um deles as Ideias Centrais ou Ancoragens e as suas respectivas Expressões Chave; com as Ideias Centrais/Ancoragens e Expressões Chave similares produzir-se-á uma ou várias sínteses discursivas que são os Discursos do Sujeito Coletivo.

Realizadas as entrevistas e feitas as transcrições, todo o material é lido cuidadosamente para posterior análise, assim teremos as Expressões Chave e Ideias Centrais para cada uma das respostas da entrevista.

Terminada esta etapa, segue-se para o momento de inserção das respostas, Expressões Chave e Ideias Centrais no sistema e suas codificações inseridas na base do Qualiquantisoft (versões 2015/16).

Nesse processo, optou-se pelo não aprofundamento da análise em Ancoragens, visto que não houve a intenção em um aprofundamento nas representações, crenças e valores dos entrevistados sobre os temas abordados, mas sim em buscar a percepção dos sujeitos acerca dos temas propostos na pesquisa, que usualmente surgem em sua realidade de trabalho separadamente e não em conjunto.

Finalizado o processo, identificamos as Expressões Chave e Ideias Centrais similares e complementares, agrupando-as em categorias, identificadas no decorrer da análise, e que permitirão o surgimento de um discurso único para o conjunto de entrevistas/depoimentos de uma mesma categoria. Os dados qualitativos da investigação foram assim alcançados.

Dados processados e os resultados compilados, tanto qualitativos quanto quantitativos, chegamos aos resultados e discussões propriamente ditos, desenvolvidos à luz da revisão de literatura e análise documental sistematizados ao longo desta pesquisa.

\section{Sujeitos do Estudo}

Para a análise, foram consideradas 25 entrevistas com conselheiros de saúde, desses, nove do sexo feminino e 16 masculino, com idades entre 28 e 75 anos e média de 54. Entre as conselheiras, a idade média é de 56 anos e os conselheiros em 50 anos.

Quanto a escolaridade, do total de conselheiros, seis tinham nível médio completo, dois com nível superior incompleto, 14 com nível superior completo, duas conselheiras com mestrado e apenas uma com doutorado. Estes registros apontam o 
elevado nível de formação escolar do grupo.

O estudo, a princípio, priorizava conselheiros estaduais de saúde, no entanto, dois conselheiros entrevistados também assumiam a função como conselheiros municipais em suas respectivas cidades, e apenas um nas três esferas. Também participou a presidente do Conselho Nacional de Saúde à época. No que tange a representação, 19 representavam o segmento usuário, quatro os profissionais de saúde e dois representando a gestão. Uma boa oportunidade de análise da inclusão digital, em se tratando de atores sociais advindos da população.

O roteiro de entrevista (Apêndice 4), contendo 36 questões, sendo 32 objetivas e quatro subjetivas, teve como objetivo provocar o entrevistado quanto ao seu conhecimento sobre o PID e outra especificidades de interesse desta pesquisa. Seus resultados serão conhecidos mais adiante.

\section{Limites do Estudo}

A coleta de dados nos Conselhos Estaduais de Saúde para diagnosticar o cenário de inclusão digital dos conselheiros deu-se por meio de entrevistas presenciais e por telefone, ambas gravadas, contemplando assim a quase totalidade das unidades da federação, uma vez que Goiás serviu como piloto na aplicação do questionário e Tocantins não atendeu às agendas de entrevista solicitadas por cinco vezes consecutivas, seja por telefone ou presencial. No caso específico do Espírito Santo, a gravação ficou inaudível após diversas tentativas de limpeza do material sonoro colhido.

O deslocamento físico para todas as capitais também foi impossibilitado, no entanto, com a parceria do Conselho Nacional de Saúde, nos foi viabilizado o acesso às reuniões do CNS, durante as sessões extraordinárias de planejamento da $15^{\mathrm{a}}$ Conferência Nacional de Saúde, tornando assim um limite numa facilidade de pesquisa.

\section{Questões Éticas}

Esta pesquisa foi aprovada pelo Comitê de Ética da Universidade de Brasília, sob o número 1.227.446 (Apêndice 1).

Como garantias aos sujeitos de pesquisa, foram aplicados o Termo de Consentimento Livre Esclarecido (TCLE) (Apêndice 2) e o Termo de Autorização para Utilização de Imagem e Som de Voz para Fins de Pesquisa (Apêndice 3). 


\section{RESULTADOS E DISCUSSÕES}

Os resultados estão descritos a seguir, divididos em quatro blocos de análise qualiquantitativa. O primeiro diz respeito a percepção dos conselheiros em relação às TIC como estratégia para fortalecimento do controle social. O segundo traz dados quantitativos referentes ao estágio de implementação do programa, informado pelos conselheiros entrevistados a partir de perguntas objetivas constantes no questionário. $\mathrm{O}$ terceiro bloco, aborda a articulação entre a infraestrutura, a formação, os conceitos e aspectos sociais e humanos. O quarto e último bloco, voltou-se a uma breve ponderação por parte dos conselheiros sobre o cumprimento das metas e objetivos do programa.

O estudo priorizou conselheiros estaduais de saúde, no entanto, dois conselheiros entrevistados também assumiam o cargo de conselheiros municipais em seus respectivos estados, e um nas três esferas. Também participou a presidente do Conselho Nacional de Saúde à época. Foram realizadas, assim, 25 entrevistas, apoiadas por um questionário contendo 36 questões, sendo 31 objetivas e quatro subjetivas.

Todos os discursos por categoria e discursos do sujeito coletivo estão presentes no apêndice 9.

\section{TIC COMO ESTRATÉGIA DE FORTALECIMENTO DO CONTROLE SOCIAL}

Neste primeiro bloco de análise, foi perguntado aos conselheiros, de que forma as tecnologias de informação e comunicação podem fortalecer as ações do conselho. O intuito desta indagação foi compreender, na percepção dos conselheiros, como deveria ser a aplicação ideal das tecnologias da informação e comunicação para o exercício do controle social.

Essa questão deu origem a cinco categorias baseadas na análise dos discursos destes conselheiros. Estas categorias consistem em afirmações extraídas das falas dos entrevistados.

Categoria A - O uso das TIC fortalece as ações cotidianas do conselho.

Categoria B - Não se aplica.

Categoria C- Promove a participação social.

Categoria D - Facilita a comunicação. 
Categoria E - O uso da TIC fortalece o controle social.

\section{Discurso do sujeito coletivo}

Tudo que se faz hoje dentro do conselho tem a participação de tecnologia. Desde um simples telefonema a um jornal, uma impressão, ou seja, por meio da tecnologia é que se pode desenvolver as ações, planejamentos, comunicação com outros conselhos e além disso, divulgar atividades. É importantíssimo que se tenha tecnologia para facilitar, pois acredito que nós precisamos interagir. Para isto, os equipamentos devem estar disponíveis para os conselheiros de modo a viabilizar a informação, pesquisa e reprodução de material. As tecnologias podem transformar para melhor uma sociedade, mais participativa não só na saúde, com o viés de aproximar e de oferecer oportunidade para que todos estejam antenados numa mesma sintonia. É através dela que conseguimos ter agilidade na comunicação e informações, com mecanismos que facilitam muito o trabalho quando necessário uma mobilização ou capacitação. Comunicação é fundamental dentro de um conselho de saúde, porém, as tecnologias precisam ser compreendidas pelos conselheiros quanto as possibilidades de comunicação via tecnologia da informação, como reuniões virtuais, filmagens e uso de toda a estrutura que existe instalada. Talvez à medida em que formos experimentando, poderemos ousar mais. Nós temos informação chegando em tempo real para toda a sociedade. Para o controle social acaba sendo um elemento facilitador, podendo ajudar o conselheiro de saúde a se expressar melhor e ter condições de exercer sua função. Por isso, cursos para os conselheiros são importantes, isso nos fortalece muito. Existem atribuições que ficam limitadas por conta de dificuldades técnicas que o conselheiro tem, tanto no uso desses instrumentos como também na pouca oportunidade de cursos que são oferecidos nessa linha. A formação política é necessária, mas a formação técnica também, pois agrega qualidade à atuação do conselho.

É com base nessas expectativas que o PID começa a ser idealizado, conforme consta no relatório final do Seminário Nacional de Comunicação, Informação e Informática em Saúde para o Exercício do Controle Social, publicado em 2006 (Brasil, 2006).

Percebe-se no discurso do sujeito coletivo, que ao idealizarem uma ação no 
âmbito da informação em saúde para exercício do controle social, os conselheiros ressaltaram a importância das ferramentas digitais no cotidiano da sociedade contemporânea. Assim, a revolução tecnológica passa a se relacionar com as consequências de distintas maneiras de participação do indivíduo no processo decisório, tratando-se assim de uma filosofia da tecnologia (NEDER, 2010).

A possibilidade ideológica de conectividade à sociedade da informação proporcionando o fortalecimento da cidadania e a construção de um diálogo baseado numa racionalidade comunicativa, é objetivo dos projetos de inclusão digital, que certamente, dependem da evolução das ferramentas, linguagens e recursos educacionais. Embora imprecisa, a expressão sociedade da informação visa descrever as novas configurações socioculturais, impulsionadas pela convergência tecnológica entre informática, comunicação e a produção do conhecimento, caracterizada pelo desenvolvimento de redes de informação (LEMOS, 2005).

A consequência do acesso rápido, quase instantâneo, lança o desafio de adaptar os dados e a comunicação da gestão pública aos softwares, sistemas de informação, aplicativos e serviços que funcionem em plataformas digitais. Essa realidade amplia o papel e a importância das TIC sobretudo, com ações que deem visibilidade às metodologias e estratégias comunicativas e uso das tecnologias, no desenvolvimento de ações de promoção, comunicação e informação em saúde para o controle social.

\section{ESTÁGIO DA IMPLEMENTAÇÃO DO PROGRAMA DE INCLUSÃO DIGITAL (PID) DE ACORDO COM OS CONSELHEIROS ENTREVISTADOS}

Segundo dados da SGEP/MS, esta secretaria disponibilizou para o PID computadores, impressoras e um kit com uma TV de 32 polegadas, decodificador e antena parabólica, grade de programação composta por canais obrigatórios, públicos, abertos, um canal de notícias e um canal com conteúdo exclusivo para assinantes da operadora, sem ônus financeiro, destinados a:

- $\quad$ 5.564 Conselhos Municipais de Saúde;

- 26 Conselhos Estaduais de Saúde;

- 1 Conselho de Saúde do Distrito Federal;

- 26 Conselhos de Secretarias Municipais de Saúde (COSEMS);

- 26 Núcleos do Ministério da Saúde nos estados; 
- 34 Conselhos de Saúde Indígenas (CONDISIS);

- 91 Entidades de Ensino - Universidades, Escolas Técnicas e Tele-saúde.

Foram escolhidos, por sorteio, dez conselhos de saúde (dois por região do país): os estaduais de Goiás, Roraima, Sergipe e os municipais de Adrianópolis/PR, Cáceres/MT, Colinas do Tocantins/TO, Gravataí/RS, Itabaiana/SE, Itapeva/SP e Montes Claros/MG. Esses conselhos, da chamada etapa piloto, participaram dos dois módulos de capacitação. Ainda em 2006, o piloto ofertou o curso de Introdução à Informática e Acesso à Internet, ministrado pelo Banco do Brasil. Em maio de 2007, eles concluíram o segundo módulo, ministrado pelo CNS, Escola Nacional de Saúde Pública Sérgio Arouca (ENSP/Fiocruz) e SGEP/MS, com conteúdos sobre Informação, Comunicação em Saúde e Controle Social.

Os dados sobre entrega de equipamentos, apresentados no Gráfico 1 por unidades da federação, foram fornecidos pelo Ministério da Saúde, por meio do Departamento de Apoio a Gestão Estratégica Participativa (DAGEP/MS) - que é responsável pela materialização, acompanhamento e monitoramento da entrega dos equipamentos.

Gráfico 1 - Distribuição dos equipamentos por Estado. 
Neste segundo bloco de análise, foi perguntado aos conselheiros, se eles conheciam ou já ouviram falar do PID, sobre uso e posse de recursos de TIC, e sobre atividades desempenhadas na área de tecnologia. Essas questões resultaram em dados quantitativos que demonstram o marco sobre o estágio atual de implementação do programa.

No que toca ao uso de TIC pelos conselheiros, foram feitas duas sequências de perguntas. A primeira, sobre o acesso as seguintes tecnologias: telefone fixo, telefone móvel, computador, internet e recursos multimídia como máquinas fotográficas, gravadores de áudio e filmadoras, e na segunda os entrevistados foram questionados se possuíam tais tecnologias em âmbito domiciliar e pessoal.

Quanto ao uso de telefone fixo, todos afirmaram ter acesso diário, no entanto, três afirmaram não ter este serviço privado, ou seja, em seus domicílios. Já em relação ao telefone móvel, embora todos tenham alegado possuir tal tecnologia, dois conselheiros afirmaram não terem acesso diário. Segundo resultados publicados no relatório da Pesquisa Nacional por Amostras de Domicílio (PNAD) 2011, houve um aumento no número de domicílios com telefone fixo na ordem de 11,8\% entre os anos de 2009 e 2011 (BRASIL, 2012). Ainda no que se refere ao uso de telefone móvel, a série histórica entre 2008 e 2012 publicado no relatório TIC Domicílio e Empresas 2012 (Brasil, 2013), mostra que no ano de 2012 o percentual de indivíduos que faziam uso de telefone celular no Brasil era de $84 \%$, enquanto que os indivíduos que tinham posse do dispositivo eram 80\%. Assim como no censo, os resultados obtidos demonstram que existem uma sutil diferença entre o acesso e a posse. Eles também acompanham os dados censitários que demonstram a popularização de uso do telefone fixo ou móvel.

Em relação aos recursos multimídia como máquinas fotográficas, gravadores de áudio e filmadoras, 18 (72\%) conselheiros disseram ter acesso diário a estes recursos, enquanto que sete (28\%) não possuíam acesso. Em domínio privado, 19 afirmaram ter alguns destes recursos, três disseram não possuir e outros três disseram usar esses recursos através do seu telefone celular.

Quando questionados sobre o uso de computador, dois conselheiros disseram não acessar diariamente o equipamento, entretanto, todos alegaram possuir computador em âmbito privado. Em relação ao uso da internet, todos afirmaram ter acesso diário, enquanto que apenas um conselheiro afirmou não ter o serviço privado. Ainda de acordo com relatório da PNAD 2012, entre 2009 e 2011 houve um aumento no número de usuários de internet com dez anos ou mais na ordem de 14,7\%, um acréscimo de quase 
10 milhões de pessoas, totalizando 46,5\% da população (BRASIL, 2012).

Foram consultados, ainda, sobre atividades na área de tecnologia que se sentiam aptos a realizar, a saber: e-mail, navegar em sites, uso de mídias sociais como Facebook e Twitter, uso de sistemas on-line como bancos e site de compras, edição de imagens, edição de vídeos, criar sites e blogs, desenvolver programas/aplicativos e promover oficinas (Gráfico 2).

Gráfico 2 - Atividades em TIC que se sentem aptos a realizar.

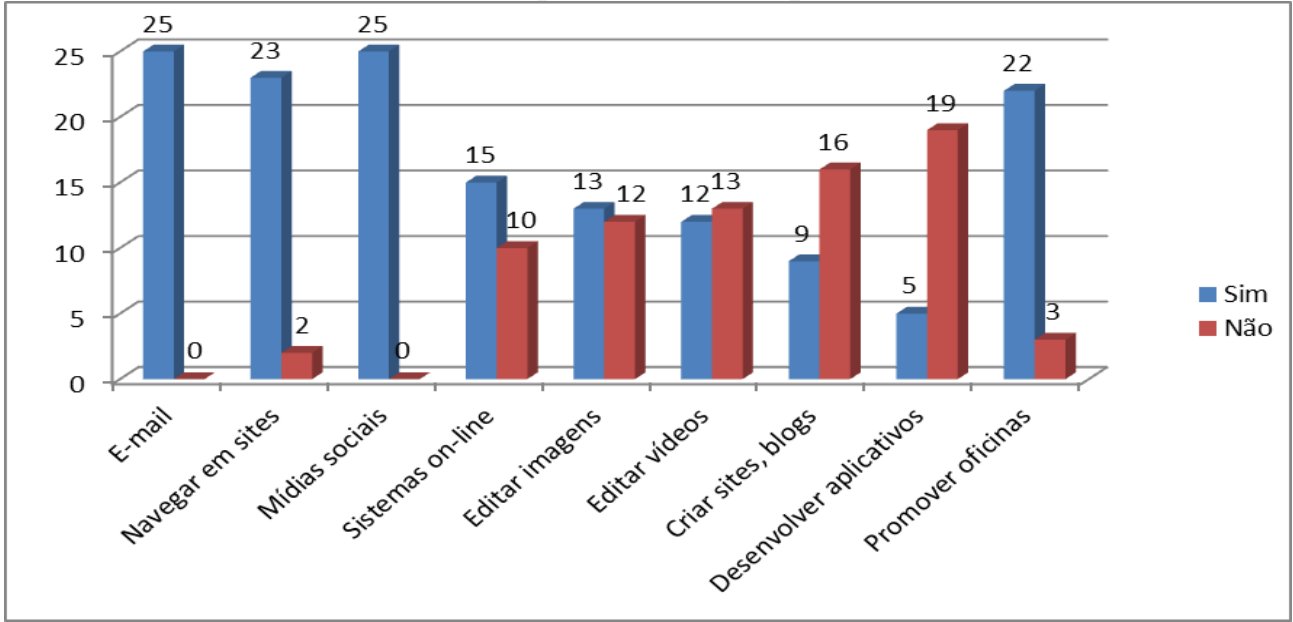

Fonte: Elaboração do autor.

Estes resultados exemplificam o nível de aptidão dos conselheiros para a realização de atividades comuns como envio de e-mail, navegação e uso de mídias sociais.

No que toca o uso de sistemas on-line, ainda que a maior parte tenha afirmado sentir-se apto, foi possível perceber durante as entrevistas a falta de confiança por parte dos conselheiros nestes serviços, o que poderia ter levado dez conselheiros a responderem "Não" quando questionados sobre o uso.

Aos que responderam "Sim" na pergunta "Promover oficinas", também foi indagado o tipo de oficina promovida. Conforme disposto na tabela 1 , diversas foram as oficinas citadas, dentre elas, algumas se destacam como "Capacitação para o uso dos equipamentos" (03), "Palestras" (02) e "Controle Social" (02).

Tabela 1 - Oficinas promovidas pelos conselheiros

\begin{tabular}{l|l} 
Promover oficinas - quais? & Vezes citada \\
\hline Qualificação de conselheiros & 1 \\
\hline Reuniões virtuais & 1 \\
\hline Transmissão ao vivo & 1 \\
\hline
\end{tabular}




\begin{tabular}{l|l}
\hline Controle social & 2 \\
\hline Capacitação para uso dos equipamentos & 3 \\
\hline do PID & 2 \\
\hline Facebook & 1 \\
\hline Palestras & 2 \\
\hline Saúde da mulher & 1 \\
\hline Montagem de projetos & 1 \\
\hline Sexo seguro & 1 \\
\hline Conselho de saúde & 1 \\
\hline Educação permanente & 1 \\
\hline Inclusão digital & 1 \\
\hline Educação em saúde & 1
\end{tabular}

Fonte: Elaboração do autor.

Embora algumas das oficinas citadas, à primeira vista, não tenham vínculo com tecnologia, alguns conselheiro alegaram fazer usos de recursos de TIC para realizá-las.

Assim, encerramos o bloco de perguntas relacionadas a uso, posse e desenvolvimento de atividades com TIC, seguindo para questionamentos sobre a infraestrutura do PID.

Ao serem questionados se conheciam o PID, 18 conselheiros disseram conhecer todas as etapas, enquanto sete afirmaram ter ouvido falar. Este resultado demonstra que pode haver uma fragilidade na divulgação de informações sobre o programa. Mesmo nos conselhos estaduais, o PID parece não possuir muita visibilidade, ainda que nenhum conselheiro tivesse afirmado desconhecimento total sobre o programa.

O gráfico 3 expõe os dados informados pelos conselheiros sobre a entrega dos equipamentos do programa em seu conselho. Dos 25 conselheiros entrevistados, aproximadamente 68\% confirmou a entrega. Os que não souberam responder, ou não responderam esta pergunta, em geral, se referem a antena, decodificador e pacote de canais de TV. Embora 21 de 25 conselheiros entrevistados confirmassem a entrega da conexão de internet, esta não faz parte do programa uma vez que o pilar conectividade ainda não havia sido implementado. 
Gráfico 3 - Entrega de equipamentos

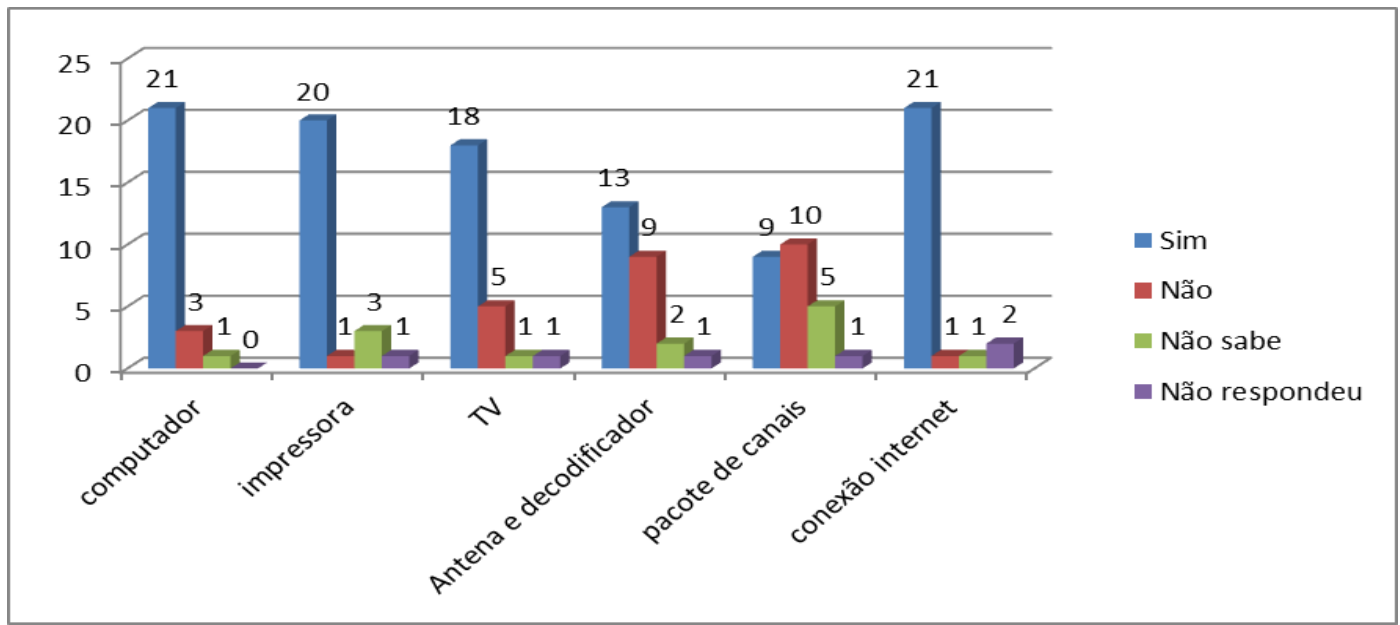

Fonte: Elaboração do autor.

Em seguida, questionou-se como os conselheiros faziam uso dos equipamentos disponíveis no conselho. Notou-se um predomínio da atividade de envio de e-mail. A tabela 2 descreve as respostas e a frequência em que as mesmas eram citadas nos discursos dos conselheiros.

Tabela 2 - Uso dos equipamentos no cotidiano dos conselheiros.

\begin{tabular}{l|l} 
Uso dos equipamentos & $\begin{array}{l}\text { Frequência de citação nos } \\
\text { discursos }\end{array}$ \\
\hline Pesquisa & 2 \\
\hline E-mail & 9 \\
\hline Download de arquivos & 1 \\
\hline Relatório & 1 \\
\hline Internet & 1 \\
\hline Uso o computador & 2 \\
\hline Impressão & 3 \\
\hline Apresentação & 1 \\
\hline Reunião & 1 \\
\hline Comunicação & 2 \\
\hline Facebook & 1 \\
\hline Gestão Controle Social & 1 \\
\hline Divulgação SUS & 1 \\
\hline SIACS & 1 \\
\hline SARGSUS & 1 \\
\hline Navegar em sites & 1 \\
\hline Telefone & 1 \\
\hline Informação & 1 \\
\hline
\end{tabular}

Fonte: Elaboração do autor 
Confrontando com a questão sobre acesso e posse de TIC, nota-se que, apesar de informarem ter acesso diário aos equipamentos elencados, o seu uso ainda apresenta-se a níveis básicos, levantando questões sobre a real apropriação do PID por parte dos conselheiros. O perfil de acesso informado leva a crer que os conselheiros já estão aptos a utilizarem os equipamentos mesmo sem a formação oferecida pelo programa.

Ainda sobre questões que abordam a infraestrutura técnica ofertada pelo PID, em uma pergunta objetiva com as alternativas Muito bom, Bom, Ruim e Muito ruim, os conselhos qualificaram os aparelhos entregues, de um modo geral. O resultado é mostrado no gráfico 4. Pode-se perceber a maioria dos conselheiros como bom ou muito bom os aparelhos entregues.

Gráfico 4 - Como os conselheiros qualificam os equipamentos recebidos

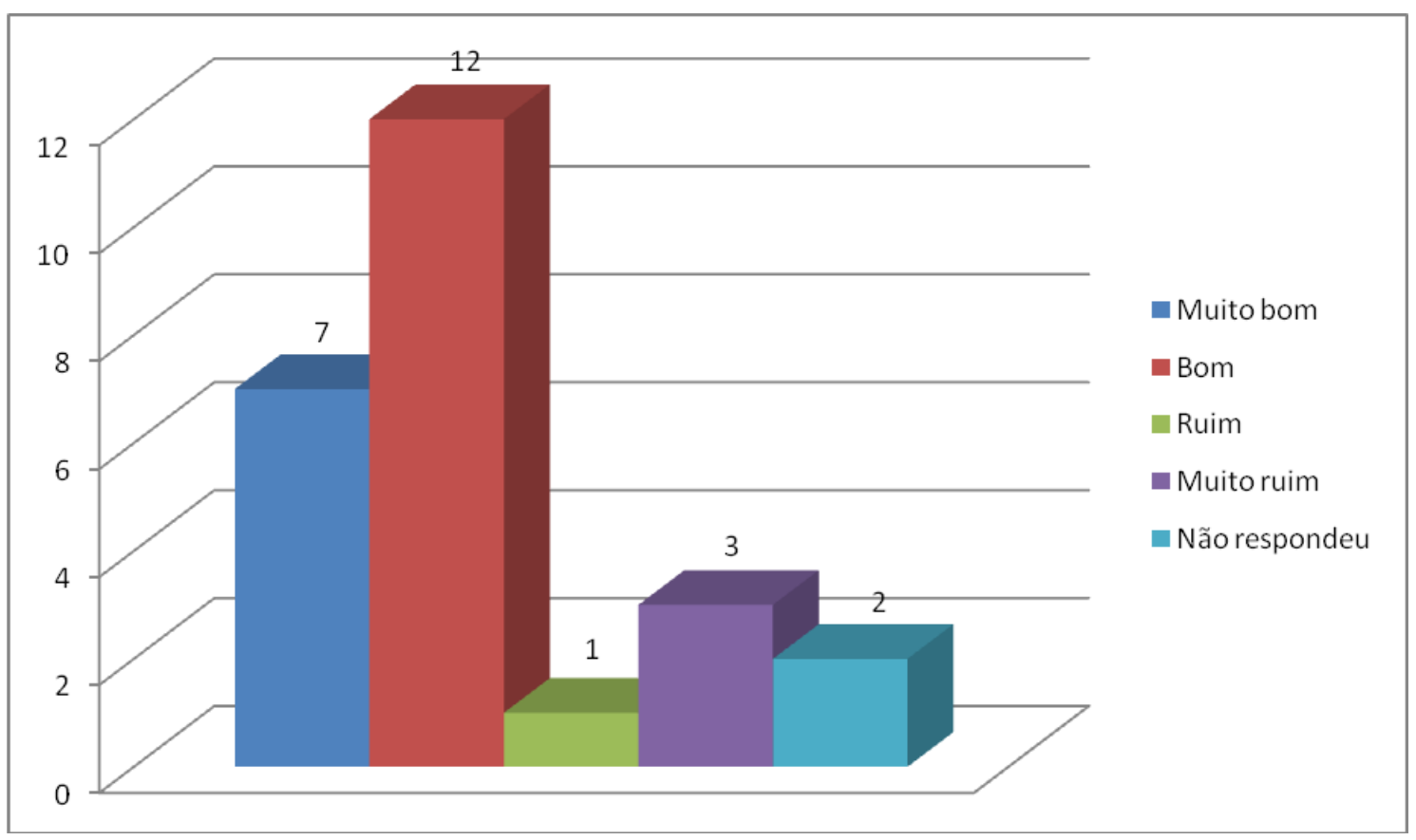

Fonte: Elaboração do autor

As questões referentes a infraestrutura oferecida pelo programa foram quantificadas para que fosse possível entender o nível de maturidade do PID nos locais pesquisados. Apesar das perguntas objetivas, os entrevistados extrapolaram as respostas ao expressarem considerações sobre os equipamentos entregues pelo programa, bem como o seu uso. O que nos dá uma breve ideia de como os conselheiros qualificam o parque tecnológico disponibilizado pelo PID. 


\section{FORMAÇÃO E ASPECTOS SOCIAIS E HUMANOS.}

Miranda e colaboradores (2005) apontaram que projetos de inclusão digital estão envoltos em um contexto tríade, composto pelo conteúdo, acessibilidade e capacitação.

Neste bloco, buscou-se avaliar o curso de formação em Informática para Conselheiros de Saúde, elaborado e oferecido pelo DATASUS por meio de questões objetivas sobre aspectos elencados: professores, conteúdo, metodologia e duração, organização, interação com o grupo, desenvolvimento pessoal e material didático por meio das alternativas muito bom, bom, ruim e muito ruim. O discurso dos conselheiros que afirmaram ter participado do curso, possibilitou o entendimento sobre aspectos sociais e humanos que se referem a apropriação da tecnologia no contexto da sua realidade. Os entrevistados também foram questionados sobre sua participação em outros cursos voltados ao uso de TIC.

Dos conselheiros entrevistados, 14 participaram do curso oferecido pelo DATASUS enquanto os outros 11 não. Aos que participaram foram feitas perguntas sobre aspectos do curso de acordo com a percepção de cada conselheiro, dispostos no gráfico 5. Todos os aspectos investigados foram, de um modo geral, bem avaliados, com destaque para os quesitos duração, desenvolvimento pessoal e metodologia.

Gráfico 5 - Percepção dos entrevistados que realizaram o curso de formação do DATASUS.

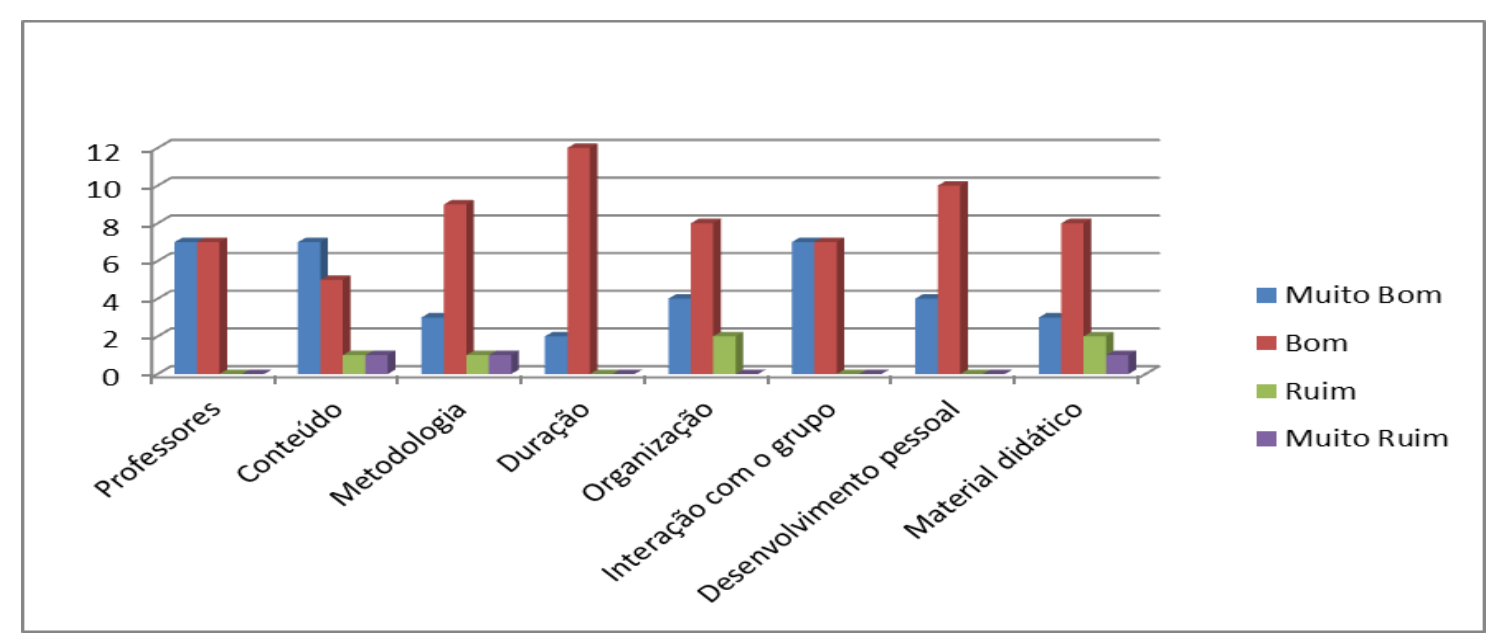

Fonte: Elaboração do autor 
Os conselheiros que não participaram do curso de formação do DATASUS, destacaram que não o fizeram por alguns motivo, tal como: não foi ofertado, razões particulares ou por outras razões apresentadas na tabela 3.

Tabela 3 - Motivos pelos quais os conselheiros não participaram do curso do DATASUS

\begin{tabular}{l|l} 
Por que não participou do curso do DATASUS? & Numero de conselheiros \\
\hline Não foi ofertado & 4 \\
\hline Razões particulares & 3 \\
\hline Não achou necessário & 2 \\
\hline Não foi divulgado & 1 \\
\hline Não houve vaga suficiente & 1
\end{tabular}

Fonte: Elaboração do autor

Para todos os entrevistados foi perguntado se havia participado de outro curso na área de tecnologia que não o ofertado pelo DATASUS. Sete informaram ter participado enquanto os outros 18 não. Esta pergunta teve o intuito de observar se houveram formações complementares aquela oferecida no âmbito do PID.

Ainda nessa linha, um achado importante resultou do cruzamento das informações referentes a participação nos cursos. Do total, seis conselheiros participaram do curso do PID e buscaram um curso complementar para qualificar o uso da tecnologia no exercício da sua atividade. Oito conselheiros realizaram o curso do PID e não buscaram um curso complementar. Um conselheiro apenas realizou o curso complementar enquanto 10 conselheiros não realizaram nenhum tipo de formação.

Afim de qualificar os dados sobre participação e entender qual a percepção dos entrevistados em relação ao impacto do curso de formação no seu cotidiano, foi perguntado que tipo de conhecimento o curso de formação do DATASUS lhe agregou, para além dos que o(a) senhor(a) já tinha, no uso das tecnologias de informação e comunicação. Esta pergunta deu origem a quatro categorias onde uma em que nenhuma das respostas se aplicava. Categoria A - Agregou conhecimento no uso das TIC; categoria B - Não se aplica; categoria C - Empoderamento; e categoria D - Melhora no desempenho das ações de conselheiro. 


\section{Discurso do Sujeito Coletivo}

Eu acredito que o curso colabora muito, somando o meu conhecimento teórico com o conhecimento prático dos técnicos do PID. Eu enriqueci muito minha formação para contribuir na formação dos outros Conselheiros. Eu não tinha nenhum conhecimento e me agregou muito, inclusive nos sites que eu não conhecia, como é fazer o e-mail, fazer essa parte de blog, facebook, foi muito legal. Facilitou o acesso a sites que são importantes em consultas para os conselheiros. Mas, falta muito ainda, mas só o pouquinho que teve foi bom. Conseguimos avançar mais um pouco e deixar de ter medo de usar os equipamentos. A gente aprendeu bastante. Me auxiliou também na busca de sistemas que pudessem me fornecer informes sobre o relatório anual de gestão, planos de saúde, regiões de saúde, macro regiões de saúde, e outros sistemas. Para ser uma pessoa mais intelectual ao sistema que vivenciamos hoje com a tecnologia avançada, no aprimoramento para a utilização de abrir programas, usar os instrumentos para eu acessar algumas coisas em Brasília, enfim, foi de suma importância para mim. Eu sou gestor da área de informática e necessariamente não precisava do curso. Eu poderia dizer para você que é instrumentalizar tecnicamente o Conselheiro para que ele possa usar também essas ferramentas tecnológicas para ter mais informação e exercer melhor sua atribuição. O curso me deu maior autonomia, e ainda o empoderamento do território. O curso me ajudou a descobrir o caminho das pedras e a conhecer locais onde posso buscar informações, empoderar para poder executar melhor o controle social. Buscar na mídia a questão dos conselhos, de formação, como os conselhos são formados, as leis. Enfim, não preciso pegar o livro, eu entro na mídia eu pesquiso proporcionando uma abertura para perder o medo de utilizar estas tecnologias. Me agregou a ter um funcionamento melhor junto das discussões e das políticas públicas.

Para os conselheiros que não participaram do curso de formação do DATASUS, foi questionado que tipo de conhecimento o PID lhe agregou, para além dos que já tinha, no uso das tecnologias de informação e comunicação. Esta pergunta deu origem a três categorias onde uma em que nenhuma das respostas se aplicava. Categoria 
A - Não se aplica,; categoria B - O PID não agregou conhecimento; e categoria C - O PID agregou conhecimento

\section{Discurso do sujeito coletivo}

Não surtiu o efeito que deveria, para o qual foi proposto. Não tenho como falar o que me agregou porque eu não tenho participado diretamente dos benefícios do programa. Vivo a questão da tecnologia e informação independente do PID. O fato de ter ou não o programa, não mudou nada. Até trouxe informações que são acompanhadas mensalmente pelas comissões do conselho, o que aproximou mais as informações e a realidade, mas não adianta ir para regiões para fazer outras coisas se as pessoas não tem acesso à internet.

Analisando as respostas sobre o pilar de formação do PID, percebeu-se que os conselheiros valorizam o conhecimento técnico e acreditam que este tipo de conhecimento pode ajudar nas atividades do dia a dia, mas que o conteúdo ofertado ainda é insuficiente.

Alguns entrevistados afirmaram que o curso ajudou a romper a barreira da apropriação do digital, ou seja, deixou-os desinibidos em relação ao uso dos equipamentos. Fizeram referência ao uso dos sistemas de gestão para o controle social, afirmando que esta facilidade foi em virtude dos cursos do DATASUS. Ressaltaram a importância de instrumentalizar o conselho para obter mais informação para o exercício das suas funções. Repetidas vezes falou-se em autonomia e empoderamento resultante da possibilidade que as TIC trazem no quesito busca de informação, sobretudo na participação em discussões sobre políticas públicas. Este discurso tem origem a partir de uma questão feita apenas aos conselheiros que participaram do curso oferecido pelo DATASUS.

Em contraponto, os conselheiros que não participaram do curso do DATASUS, ao serem questionados sobre que tipo de conhecimento o PID lhe agregou para além dos que já tinham, afirmaram que utilizam tecnologia independente do PID e que o programa não agregou conhecimento para além do que já possuíam. O fato das localidades não estarem totalmente conectadas foi citado como um ponto negativo à execução do programa e que as informações obtidas através dele, por isso, não estavam sendo devidamente difundidas. 


\section{BREVE PONDERAÇÃO POR PARTE DOS CONSELHEIROS SOBRE O CUMPRIMENTO DO OBJETIVO DO PROGRAMA.}

O objetivo principal do PID é contribuir para que os conselheiros de saúde se apropriem de informações e adquiram habilidades para comunicação indispensáveis ao exercício do controle social, por meio de equipamentos e informação em saúde. Nesse sentido, foi perguntado aos entrevistados se, em sua opinião e no contexto de sua cidade, o programa atinge este objetivo e como. Dessa pergunta surgiram quatro categorias: categoria A- O PID não atingiu o objetivo; categoria B - Não se aplica categoria C- O PID atinge o objetivo com ressalvas; e categoria D - O PID atinge o objetivo.

\section{Discurso do sujeito coletivo}

Eu acredito que atinge o objetivo, mas não como os diretores, os coordenadores do PID nacional pensam. É preciso ainda melhorar. Devemos entender que existem ribeirinhos, indígenas, quilombolas, idosos dentro desses conselhos, então é preciso que haja um sistema que dê acesso diretamente a informação, que englobe todas elas, pois o que mais vejo é o retalhamento das informações. O programa empodera, passa confiança, tira inclusive um pouco do medo. Existe uma certa insegurança na maioria de nós, contudo o curso chega para mostrar que é possível a gente entrar de cabeça e poder com isso tirar todo o proveito necessário para a melhoria, para a qualificação da atuação dos conselheiros, mas isso é algo insuficiente ainda. A gente poderia estar muito melhor se os gestores deixassem os conselhos trabalharem. Em alguns municípios, a maioria dos equipamentos não estão disponíveis e, onde foram disponibilizadas salas para os equipamentos, temos o controle social muito melhor, mais fortalecido. Era para ter sido feita uma capacitação, porém a única coisa que a gente tem feito é repassar as informações que o Ministério manda. Eu trocaria a palavra controle social por participação social porque ele foi além da saúde. Quando ele (PID) não conseguiu organizar o conselho, organizou a escola do bairro, conseguiu minimizar a agressão daquela região, daquele território, então foi muito bom. Pena que a gente não conseguiu fazer com que essa resposta fosse coletiva. 
Defendo esse programa no sentido da gente buscar avançar o controle social e ter maior proximidade daqueles que estão no dia a dia com a sociedade, e também haver uma interlocução, uma interação interconceitos. No entanto, o PID tem uma concepção ampla que o controle social não se apropriou ficando muito na entrega de equipamentos e no monitoramento desses. É preciso um planejamento no conselho para que isso venha a acontecer, do contrário o programa vai ficar como mais um produto colocado sem a devida utilização. Então falta política, falta foco dos próprios conselhos e dos próprios gestores para que o PID possa atingir esse objetivo. Dificuldades como a não aquisição e até mesmo de não haver um local próprio para uso, com infraestrutura básica, faz com que os equipamentos sejam deslocados para outros locais. Precisamos combater isso de todas as formas, para que os equipamentos estejam sempre a disposição dos conselheiros. O PID foi a grande sacada do Governo Federal em relação ao controle social. Nós tínhamos conselheiros que não sabiam nem ligar um computador, hoje navegam na rede, interagem conosco, fazem perguntas e pesquisam, o que possibilita o acesso à informação e, consequentemente, o controle social fica mais fortalecido. Houve um lapso de tempo entre entrega do equipamento e a capacitação, poderia ter sido um pouco mais dinâmico. Nos deu abertura porque as pessoas podem utilizar este instrumento na própria secretaria do conselho. Eu acho que veio beneficiar, pois transformamos o que recebemos, de âmbito nacional, em informações para o município.

O discurso revela que os entrevistados acreditam que o PID alcançou o objetivo proposto, entretanto, o programa precisa ser melhorado, sobretudo para atender populações que não tem acesso direto às informações, como ribeirinhos, indígenas, quilombolas e idosos. Afirmaram também que as informações precisam ser mais bem consolidadas em sua origem para que possam ser propagadas com qualidade.

Assim, existe uma forma complexa de discriminação digital contra segmentos mais vulneráveis. O que se observa é que não se pode ignorar o distanciamento no que se refere à apropriação de tecnologia. A infraestrutura adequada é fundamental, assim como a necessidade de apropriação adequada e qualificada para o deu uso. (DEMO, 2005).

Com relação a insegurança ao uso de tecnologia, foi afirmado que o programa apoia no desenvolvimento destas competências, empoderando e aumentando a 
confiança dos conselheiros no muito em parte resultante do processo de formação oferecido. Entretanto, repetidas vezes foi afirmado que o programa ainda é insuficiente em todos os seus aspectos, ou seja, a evolução das tecnologias e sua constante inserção no ambiente dos conselhos, demanda uma urgente atualização do programa, em todos os seus aspectos. Entre as críticas mais diretas estavam a má gestão dos equipamentos, sobretudo quando o conselho não possuía autonomia sobre seu espaço.

Uma das frases mais emblemáticas se referiu aos limites do programa, pois um dos entrevistados ressaltou de forma enfática que o programa deveria extrapolar os muros do conselho impactando na coletividade, assim como ocorreu em seu município.

É fundamental que as ações de inclusão digital sejam promotoras da cidadania, contribuindo para a construção de uma relação igualitária cuja expectativa é a inclusão social. Para isso, é importante que as ações tenham em seus projetos uma base conceitual fundamentada, contemplando as novas linguagens disponíveis. Assim, é necessário que para haver inclusão haja capacitação para o acesso qualificado à informação. (SILVA, 2005).

Outra importante observação referiu-se ao PID como projeto de entrega e de equipamentos, e só realizou monitoramento destas entregas enquanto segundo seu objetivo ele deveria ter uma concepção mais ampla no que tange ao controle social. 


\section{CONSIDERAÇÕES FINAIS}

No decorrer deste estudo pode-se perceber que as ações no âmbito do PID ainda se mostram tímidas diante do seu potencial para promover a qualificação do controle social por meio das TIC. De acordo com os dados fornecidos pela SGEP/MS, no período de 2007 a 2014 foi realizada a entrega de equipamentos, prevista na etapa 1, que correspondia à infraestrutura dos conselhos para receber as demais etapas do PID, que correspondem à formação (etapa 2) e conectividade (etapa 3). A partir deste estudo percebe-se a efetivação parcial das etapas 2 e 3 do programa, uma vez que os próprios relatórios de gestão da Secretaria apontaram, diante da análise documental desenvolvida, que as mesmas não foram totalmente efetivadas.

No discurso sobre como as TIC poderiam fortalecer as ações do conselho, fica evidente o conhecimento por parte dos conselheiros das facilidades proporcionada pelas tecnologias, bem como a necessidade de entendimento sobre recursos ainda desconhecidos, não só relacionados à tecnologia, quanto ao acesso a informação por meio delas. O que, conforme os achados, consolida as ações cotidianas do conselho, promove a participação social, facilita a comunicação e fortalece o controle social.

No que toca acesso e posse de TIC, percebe-se o nível em que os estão inseridos, porém, ainda que recursos estejam disponíveis, as atividades desenvolvidas ficam, praticamente, limitadas as ações corriqueiras, levando a dúvidas sobre a verdadeira assimilação no uso de tecnologias, embora tenham consciência das possibilidades proporcionadas no âmbito da educação, informação e comunicação.

A etapa de formação ainda está em processo de efetivação, conforme compromisso publicado no portal Governo Aberto (CGU.BR, 2015), o que pode justificar o número de conselheiros que ainda não participaram do curso. Esta constatação se confirma nos motivos citados que levaram a não participação, com destaque aos relatos de não oferta do curso. Isto chama a atenção para quais são as prioridades do programa, onde, ainda conforme o documento de compromisso, primouse pela entrega de equipamentos. Mesmo sim, para os conselheiros que participaram do curso, percebe-se o bom desempenho e aceitação, segundo os discursos e a avaliação dos aspectos. Contudo, é necessária maior atenção com os processos de aprendizagem pois muitos não se sentem aptos a aprender novas linguagens baseadas no digital. Apesar da influência da sociedade digital, estas pessoas não desenvolvem habilidades para manejo autônomo de tecnologias. 
A importância dos aspectos formativos e do acesso democrático foram diversas vezes ressaltados pelos conselheiros entrevistados, de forma a demonstrar e reafirmar sua importância durante todo o percurso de implantação do programa.

Com a finalização desta pesquisa, podemos considerar que a evolução da sociedade contemporânea e a emergência de técnicas e linguagens baseadas no digital, demandam um modelo de projeto que articule infraestrutura e inovação, acompanhados de conceitos e fundamentos que permitam a apropriação qualificada destas tecnologias que impactem na qualidade de vida, e nesse particular, auxiliando os processos de cuidado de saúde dos indivíduos, família e comunidade. 


\section{REFERÊNCIAS BIBLIOGRÁFICAS}

ALMEIDA, Maria Elizabeth Bianconcini. Tecnologias e Gestão do Conhecimento na Escola. In: VIEIRA, Alexandre Thomaz, ALMEIDA, Maria Elizabeth Bianconcini de, ALONSO, Myrtes. (Org.). Gestão Educacional e Tecnologia. São Paulo: Avercamp, 2003.

ARANTES, C. I. S et al. O Controle Social no Sistema Único de Saúde: concepções e ações de enfermeiras da atenção básica. Texto \& Contexto Enfermagem, Florianópolis, v. 16, n. 3, p. 470-478, jul./set. 2007

BRASIL. Ministério da Saúde. Conselhos de saúde: a responsabilidade do controle social democrático do SUS / Ministério da Saúde, Conselho Nacional de Saúde. - 2. ed. - Brasília: Ministério da Saúde, 2013.

BRASIL Ministério da Saúde. Conselho Nacional de Saúde. Relatório do seminário nacional de comunicação, informação e informática em saúde para o exercício do controle social : Brasília, 8 e 9 de dezembro de 2005 Brasília : Editora do Ministério da Saúde, 2006.

BRASIL. Ministério da Saúde. Resolução CNS no 29 1, de 06 de maio de 1999. Dispões sobre Aprovação do Regimento Interno do Conselho Nacional de Saúde. Brasília, 1999.

BRASIL. Ministério da Saúde. 12ª . Conferência Nacional de Saúde: Conferência Sergio Arouca, Brasília, 7 a 11/12/2003. Relatório Final. Ministério da Saúde, Conselho Nacional de Saúde. Brasília: Ministério da Saúde, 2004. 230 pp

BRASIL. Lei $n^{\circ}$ 8.142, de 28 de dezembro de 1990. Dispõe sobre a participação da comunidade na gestão do Sistema Único de Saúde (SUS) e sobre as transferências intergovernamentais de recursos financeiros na área da saúde e dá outras providências. Disponível em < http://www.governoaberto.cgu.gov.br/no-brasil/planos-de-acao-1/2oplano-de-acao-brasileiro/ministerio-da-saude/inclusao-digital-dos-conselhos-de-saude> Acesso em dez 2015.

BRASIL. Inclusão Digital dos Conselhos de Saúde, Descrição do compromisso: Implementar o Programa de Inclusão Digital (PID) em todos os Conselhos Estaduais, Distrital e Municipais de Saúde, de maneira a contribuir com o aperfeiçoamento do exercício do controle social do Sistema Único de Saúde (SUS). Disponível em <http://www.planalto.gov.br/ccivil_03/leis/L8080.htm> Acesso em dez 2015.

BRASIL. Secretaria de Gestão Estratégica e Participativa (SGEP/MS). Programa de Inclusão Digital dos Conselheiros de Saúde. Disponível em < http://cosemsrs.org.br/imagens/portarias/por_o8j9.pdf>. Acesso em nov, 2014.

CGI.br. Pesquisa sobre o uso das tecnologias da informação e comunicação nos domicílios brasileiros. São Paulo: Comitê Gestor da Internet no Brasil, 2015. Disponível $<$ http://www.cgi.br/media/docs/publicacoes/2/TIC_Domicilios_2014_livro_eletronico.p df $>$ Acesso em jan 2016. 
BRAVO, Maria Inês Souza; CORREIA, Maria Valéria Costa. Desafios do controle social na atualidade. Serv Soc Soc, v. 109, p. 126-50, 2012.

CGI.br. TIC Saúde 2013: pesquisa sobre o uso das tecnologias de informação e comunicação nos estabelecimentos de saúde brasileiros. Disponível em <http://cetic.br/publicacoes/2013/tic-saude-2013.pdf>. Acesso em abr, 2014.

CAPURRO, Rafael; HJORLAND, Birger. The concept of information as we use in everyday. Perspectivas em ciência da informação, v. 12, n. 1, p. 148-207, 2007.

CARVALHO, A.L. B. et a.l Programa de Inclusão Digital - PID: o uso da informação como estratégia para o fortalecimento do controle social. Tempus - Actas de Saúde Coletiva, vol. 3, n. 3, p. 31-43, jul./set. 2009.

DEMO, Pedro. Inclusão digital: cada vez mais no centro da inclusão social. Inclusão Social, Brasília, v. 1, n. 1, p. 36-38, 2005. Disponível em:

$<$ http://revista.ibict.br/inclusao/index.php/inclusao/article/viewFile/4/8>. Acesso em: 05 dez. 2011.

DA SILVA, Alessandra Ximenes; CRUZ, Eliane Aparecida; MELO, Verbena. A importância estratégica da informação em saúde para o exercício do controle social. Ciência \& Saúde Coletiva, v. 12, n. 3, p. 683-688, 2007.

FRAGOSO, S.; RECUERO, R.; AMARAL, A. Métodos de pesquisa para internet. Porto Alegre: Editora Sulina. 2013

FREIRE, GHA. Construção participativa de instrumento de política pública para gestão e acesso à informação. Perspectivas em Ciência da Informação, v.13 n.3. Belo Horizonte set./dez. 2008

Instituto de Pesquisa do Discurso do Sujeito Coletivo (IPDSC). O que é o DSC. Disponível em: http://www.ipdsc.com.br. Acesso em jun 2015.

Lefèfre F.; Lefèfre AMC. O discurso do sujeito coletivo: um enfoque em pesquisa qualitativa (desdobramentos). Caxias do Sul: Educs; 2003.

Lefevre F.; Lefevre AMC. Pesquisa de representação social: um enfoque qualiquantitativo: a metodologia do Discurso do Sujeito Coletivo. Brasília: Líber Livro editora, 2010.

Lefevre F.; Lefevre AMC. Depoimentos e Discursos: uma proposta de análise em pesquisa social. Brasília: Liber Livro Editora; 2005. (Série Pesquisa, 12)

LAZARTE, L.; Ecologia Cognitiva na sociedade da informação. Ci. Inf., Brasília, v.29, n.2, p.43-51, maio/agosto. 2000

LEMOS, A. Um modelo de inclusão digital: o caso da cidade de Salvador. Revista de Economía Política de las Tecnologías de la Información y Comunicación, Vol. VIII, n. 6, Sep. - Dec. 2005 
MENDONÇA, AVM. A Integração de Redes Sociais e Tecnológicas: Análise do Processo de Comunicação para Inclusão Digital. Tese [Doutorado]. Universidade de Brasília, 2007.

Os processos de comunicação e o modelo todos-todos: uma relação possível com o Programa Saúde da Família. Brasília: Editora do Departamento de Ciência da Informação e Documentação da UnB; 2007.

. O processo de comunicação Todos-Todos e a produção de conteúdos: desafios à Gestão do Conhecimento. In: MOYA, J.; SANTOS, ME.; MENDONÇA, AVM. (Org.) Gestão do Conhecimento em Saúde no Brasil: avanços e perspectivas. Brasília: Organização Pan-Americana da Saúde, 2009. p. 18-24.

MENDONÇA, AVM. et al. Inclusão digital dos agentes comunitários de saúde no Brasil: novas formas de aprender em rede. Tempus - Actas de Saúde Coletiva, vol. 3, n.1, p. 28-37, jan./mar. 2009.

MINAYO, MCS; SANCHES, O. Quantitativo-Qualitativo: Oposição ou Complementaridade? Cad. Saúde Públ., Rio de Janeiro, 9 (3): 239-262, jul/set, 1993.

MOYA, J.; SANTOS, ME.; MENDONÇA, AVM. (Org.) Gestão do Conhecimento em Saúde no Brasil: avanços e perspectivas. Brasília: Organização Pan-Americana da Saúde, 2009.

MORAES, I. H. S. et al. Inclusão digital e conselheiros de saúde: uma política para a redução da desigualdade social no Brasil. Ciência \& Saúde Coletiva, 14(3):879-888, 2009

MORAES, IHS. Política, tecnologia e informação em saúde: a utopia da emancipação. Salvador: ISC/UFBA/Casa da Qualidade; 2002.

NUNES, MO. et al. O agente comunitário de saúde: construção da identidade desse personagem híbrido e polifônico. Cad. Saúde Pública, Rio de Janeiro, v. 18, n. 6, dez. 2002 .

PASSERINO, L. .; MONTARDO, S. P. Inclusão social via acessibilidade digital: proposta de inclusão digital para pessoas com necessidades especiais. Colóquio Internacional sobre a Escola Latino Americana de Comunicação, v. 11, 2007.

SILVA, H. et. al. Inclusão digital e educação para a competência informacional: uma questão de ética e cidadania. Ci. Inf. Brasília, vol.34, no. 1, 2005. p. 28-36.

SANTOS, CQ; CARDOSO, AMP. Inclusão digital e desenvolvimento local. TransInformação, Campinas, 21(1): p. 7-22, jan./abr., 2009 Disponível em $<$ http://www.scielo.br/pdf/tinf/v21n1/01.pdf > . Acesso em nov, 2014.

WARSCHAUER, M. Tecnologia e Inclusão Social. A exclusão digital em debate. São Paulo: Senac, 2006. 


\section{LISTA DE APÊNDICES}

Apêndice 1 - Aprovação do CEP ...................................................................................54

Apêndice 2 - Termo de Consentimento Livre e Esclarecido - TCLE .............................60

Apêndice 3 - Termo de Autorização para Utilização de Imagem e Som de Voz para Fins

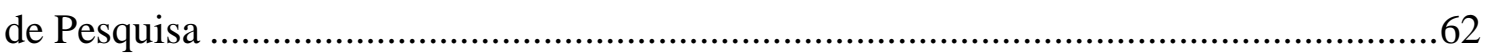

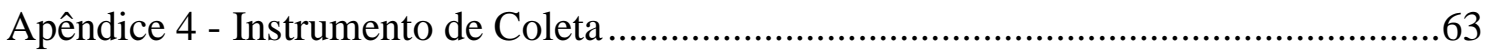

Apêndice 5 - Comprovante de submissão do artigo ......................................................68

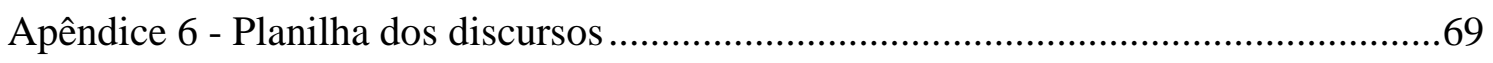

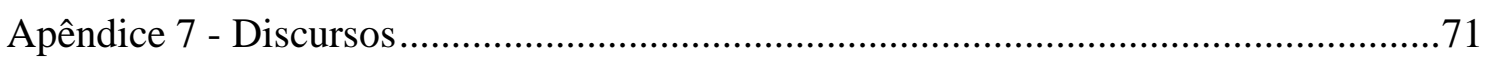




\section{Apêndice 1}

\section{Aprovação do CEP}

\section{FACULDADE DE CIÊNCIAS DA SAÚDE DA UNIVERSIDADE DE $\bigcirc$ Plataformo BRASÍLIA - CEP/FS-UNB}

PARECER CONSUBSTANCIADO DO CEP

\section{DADOS DO PROJETO DE PESQUISA}

Título da Pesquisa: Programa de Inclusão Digital dos Conselheiros de Saúde: O Uso das Tecnologias de Informação e Comunicação Auxiliam o Controle Social?

Pesquisador: Joao Paulo Fernandes da Silva

Área Temática:

Versão: 2

CAAE: 45724015.1 .0000 .0030

Instituiçāo Proponente: Departamento de Saúde Coletiva

Patrocinador Principal: Financiamento Próprio

\section{DADOS DO PARECER}

Número do Parecer: 1.227 .446

\section{Apresentação do Projeto:}

"Resumo:

Tecnologias de informação e comunicação como ferramentas integração social, surgiram como demandas das $12^{\circ}$ e $13^{\circ}$ Conferências Nacionais de Saúde, aprovado pelo Conselho Nacional de Saúde e consolidado pela Secretaria de Gestão Estratégica e Participativa, o Programa de Inclusão Digital dos Conselheiros de Saúde - PID. O programa tem por objetivo contribuir para que os conselheiros nacionais, estaduais e municipais de saúde se apropriem de informações e adquiram habilidades para comunicação indispensáveis ao exercício do controle social, por meio do acesso a equipamentos de informática, informações em saúde necessárias ao desempenho do papel de conselheiro e estabelecimento de rede de intercámbio entre os Conselhos de Saúde (SGEP/MS). Este estudo tem como objetivo de analisar a contribuição do Projeto de Inclusão Digital dos Conselheiros de Saúde no que tange a apropriação do uso de tecnologias de informação e comunicaçāo para o controle social. Estudo qualitativo/ quantitativo com revisão da literatura. Serão usados para análise dos dados coletados os softwares "Qualiquanti Software" para análise qualitativa e "Microsoft Excel" para quantitativo."

"Metodologia Proposta:

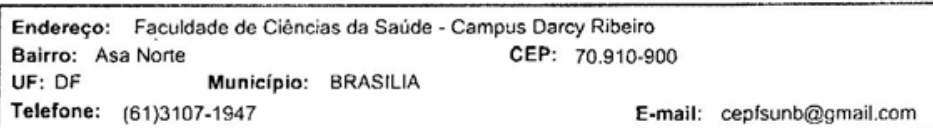




FACULDADE DE CIÊNCIAS DA
SAÚDE DA UNIVERSIDADE DE flataforma
BRASILIA - CEP/FS-UNB

Continuação do Parecer: 1.227 .446

Estudo de natureza qualitativa/quantitativa com revisão da literatura. A coleta de dados nos Conselhos Estaduais de Saúde para diagnosticar o cenário de inclusão digital dos conselheiros será feita por meio de entrevistas presenciais, por telefone, videoconferência e questionário eletrônico. A investigação junto aos profissionais quanto à percepção frente ao uso das TIC e no processo de educação continuada em saúde dar-se-á por intermédio de entrevista semiestruturada. A análise dos dados quantitativos será feita com uso do software "Microsoft Excel", enquanto a análise qualitativa será por meio do "Qualiquanti Software"."

"Serão visitados dez conselhos estaduais de saúde, com o objetivo de entrevistar, pelo menos, um conselheiro."

\section{Objetivo da Pesquisa:}

"Objetivo Primário:

Analisar a contribuição do Programa de Inclusão Digital dos Conselheiros de Saúde no que tange a apropriação do uso de tecnologias de informação e comunicação para o controle e participação social. Objetivo Secundário:

Conhecer o modelo de implantaçäo projeto; Verificar o cenário de uso das TIC nos Conselhos de Saúde; Investigar junto aos conselheiros a percepção destes frente ao uso das TIC no controle social;Refletir sobre processos de apoio à gestão municipal do SUS, no uso das Tecnologias de Informação e Comunicação em Saúde (TICS)."

\section{Avaliação dos Riscos e Beneficios:}

Segundo o pesquisador:

"Riscos:

Os riscos decorrentes da participação na pesquisa são relacionados a possiveis constrangimentos, nesse caso, o entrevistado poderá se recusar a responder (ou participar de qualquer procedimento) qualquer questão que Ihe traga constrangimento, podendo desistir de participar da pesquisa em qualquer momento sem nenhum prejuizo para o participante.

Benefícios:

Possiveis novas politicas de inclusão digital ou mesmo repensar o programa vigente."

Comentários e Considerações sobre a Pesquisa:

Trata-se de projeto de mestrado do Programa de Pós-graduação em Saúde Coletiva, orientado

\begin{tabular}{l} 
Endereço: Faculdade de Ciências da Saúde - Campus Darcy Ribeiro \\
Bairro: Asa Norte \\
$\begin{array}{l}\text { UF: DF } \\
\text { Telefone: }\end{array} \quad$ Município: BRASILIA \\
\hline
\end{tabular}




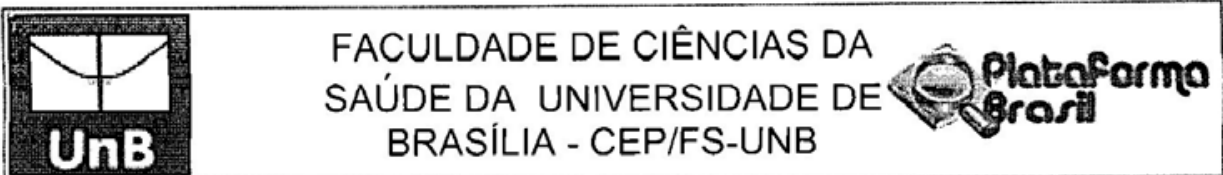

Continuação do Parecer: 1.227.446

pela Profa. Ana Valéria Machado Mendonça.

30 participantes de pesquisa.

O Cronograma de Execução da Plataforma Brasil informa realização da pesquisa entre 15/06/2015 e 18/12/2015, com etapa de "coleta de dados" de 15/08/2015 a 05/09/2015.

Apresenta Orçamento Financeiro no valor total de $\mathrm{R} \$ 8.700,00$, consistindo de materiais de papelaria gravador de áudio, passagens, hospedagem e alimentação, custeados pelo próprio pesquisador.

Consideraçöes sobre os Termos de apresentação obrigatória:

Documentos analisados para emissăo do presente parecer:

- Informações Básicas do Projeto - "PB_INFORMAÇÕES_BÁSICAS_DO_PROJETO_511763.pdf", postado em 02/09/2015;

- Carta de respostas às pendências apontadas no parecer no. 1.151.794 - "ceppendencias0001.pdf", postado em 02/09/2015;

- Projeto Detalhado - "PPGSC_mest_prof.docx", postado em 02/09/2015;

- Termo de ciência da pesquisa, assinatura e carimbo de José João Lanceiro de Palma, Secretário Executivo do Conselho Nacional de Saúde - "termodecienciadapesquisa.pdf", postado em 07/08/2015;

- Folha de Rosto, com assinatura da pesquisadora responsável, e com carimbo e assinatura da diretora da instituição proponente, a Faculdade de Ciências da Saúde (FS) da Universidade de Brasília (UnB), Profa. Maria Fátima de Sousa, e CNPJ da instituiçāo - "fr-CEP.pdf", postado em 03/08/2015;

- Termo de autorização de uso de imagem e som de voz para fins de pesquisa -

"TermoAutorizImagemSom.doc", postado em 03/08/2015;

- Instrumento de Coleta - "instrumento_final.docx", postado em 03/08/2015.

Recomendaçōes:

Não se aplica.

Conclusōes ou Pendências e Lista de Inadequações:

Análise das respostas às pendências apontadas no parecer no. 1.151.794:

1. Solicita-se informar o CNPJ da instituição proponente na folha de rosto.

Endereço: Faculdade de Cièncias da Saúde - Campus Darcy Ribeiro

Bairro: Asa Norte CEP: $70.910-900$

UF: DF Municipio: BRASILIA

Telefone: (61)3107-1947

E-mail: cepfsunb@gmail.com 


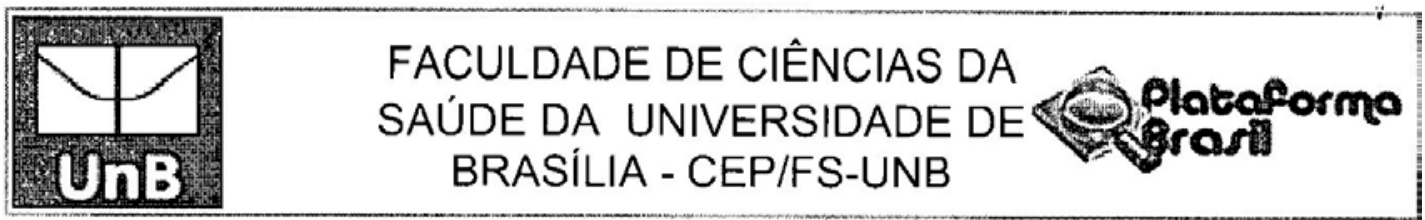

Continuaçāo do Parecer: 1.227 .446

ANÁLISE: Folha de rosto adequada apresentada no documento "fr-CEP.pdf", postado em 03/08/2015. PENDENCIA ATENDIDA

2. Solicita-se apresentar roteiro para entrevistas semiestruturadas e questionário que será apresentado eletronicamente para análise ética pelo CEP.

ANÁLISE: Documento "instrumento_final.docx", postado em 03/08/2015, apresentado aparentemente perguntas eticamente adequadas. PENDÊNCIA ATENDIDA

3. Solicita-se informar se a entrevista será gravada. Caso seja, solicita-se apresentar modelo de termo de autorização para uso de som de voz para fins de pesquisa.

ANÁLISE: Documento "TermoAutorizImagemSom.doc", postado em 03/08/2015, apresentado. PENDÉNCIA ATENDIDA

4. Solicita-se informar se o projeto de pesquisa já foi realizado, uma vez que o cronogram de execução da Plataforma Brasil informa realização da etapa de "coleta de dados" de 15/06/2015 a 20/07/2015. Caso não tenha sido iniciado, solicita-se atualização do cronograma.

ANÁLISE: No documento "PB_INFORMAÇŌES_BÁSICAS_DO_PROJETO_511763.pdf", postado em 02/09/2015, página 3 de 5, item "Cronograma de Execuçäo", a etapa de "Coleta de dados" foi atualizada para o periodo entre 15/08/2015 e 05/09/2015. PENDÊNCIA ATENDIDA

5. Solicita-se informar quais serão os dez conselhos estaduais de saúde que serão visitados.

ANÁLISE: No documento página 4 de 7, item "3. Método", lê-se: "Será entrevistado, no mínimo, um conselheiro por estado, contemplando assim todas as unidades da federação."

Informa ainda que não haverão videoconferências e formulário eletrônico, passando a ser somente entrevistas presenciais e por telefone, ambas gravadas. PENDÊNCIA ATENDIDA

6. Solicita-se apresentar termo de ciência de realização da pesquisa do Conselho Nacional de Saúde ou do Conselho Regional de Saúde. Pergunta-se, ainda, se o Conselho Nacional de Saúde poderia ser considerado como coparticipante do presente projeto.

ANÁLISE: É apresentado o documento "termodecienciadapesquisa.pdf", postado em 07/08/2015. PENDÊNCIA ATENDIDA

Protocolo de pesquisa em conformidade com a Res. CNS 466/2012 e Complementares.

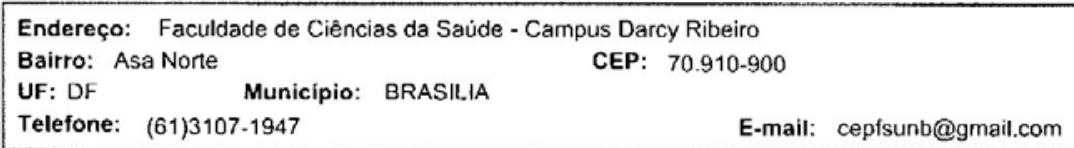




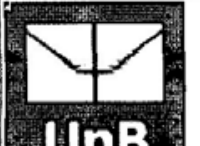

\section{FACULDADE DE CIÊNCIAS DA SAÚDE DA UNIVERSIDADE DE Slaterorma BRASÍLIA - CEP/FS-UNB}

Continuação do Parecer: 1.227 .446

Considerações Finais a critério do CEP:

Em acordo com a Resolução 466/12 CNS, itens X.1.- 3.b. e XI.2.d, os pesquisadores responsáveis deverão apresentar relatórios parcial semestral e final do projeto de pesquisa, contados a partir da data de aprovação do protocolo de pesquisa.

Este parecer foi elaborado baseado nos documentos abaixo relacionados:

\begin{tabular}{|c|c|c|c|c|}
\hline Tipo Documento & Arquivo & Postagem & Autor & Situação \\
\hline $\begin{array}{l}\text { Informações Básicas } \\
\text { do Projeto }\end{array}$ & $\begin{array}{l}\text { PB_INFORMAÇŌES_BÁSICAS_DO_P } \\
\text { ROJETO 511763.pdf }\end{array}$ & $\begin{array}{c}14 / 05 / 2015 \\
17: 45: 03\end{array}$ & & Aceito \\
\hline $\begin{array}{l}\text { TCLE / Termos de } \\
\text { Assentimento / } \\
\text { Justificativa de } \\
\text { Ausência }\end{array}$ & $\begin{array}{l}\text { Termo de Consentimento Livre e } \\
\text { Esclarecido.docx }\end{array}$ & $\begin{array}{l}01 / 06 / 2015 \\
11: 35: 16\end{array}$ & & Aceito \\
\hline Outros & $\begin{array}{l}\text { Lattes Ana Valéria Machado } \\
\text { Mendonça.pdf }\end{array}$ & $\begin{array}{c}01 / 06 / 2015 \\
11: 35: 47 \\
\end{array}$ & & Aceito \\
\hline Outros & $\begin{array}{l}\text { TermoRespCompromPesq CEPFS } \\
\text { 03.2015.doc }\end{array}$ & $\begin{array}{c}01 / 06 / 2015 \\
11: 36: 20 \\
\end{array}$ & & Aceito \\
\hline Outros & termoRespComproPesq.pdf & $\begin{array}{c}01 / 06 / 2015 \\
11: 36: 45 \\
\end{array}$ & & Aceito \\
\hline Outros & $\begin{array}{l}\text { cartaencaminhprojeto ao CEPFS } \\
05.2015 . \text { doc }\end{array}$ & $\begin{array}{c}01 / 06 / 2015 \\
11: 37: 17 \\
\end{array}$ & & Aceito \\
\hline Outros & cartaencaminhamentoCEP.pdf & $\begin{array}{c}01 / 06 / 2015 \\
11: 52: 44 \\
\end{array}$ & & Aceito \\
\hline $\begin{array}{l}\text { Informações Básicas } \\
\text { do Projeto }\end{array}$ & $\begin{array}{l}\text { PB_INFORMAÇǑES_BÁSICAS_DO_P } \\
\text { ROJETO 511763.pdf }\end{array}$ & $\begin{array}{c}01 / 06 / 2015 \\
11: 53: 43 \\
\end{array}$ & & Aceito \\
\hline Outros & instrumento_final.docx & $\begin{array}{c}03 / 08 / 2015 \\
11: 47: 14 \\
\end{array}$ & & Aceito \\
\hline Outros & TermoAutorizImagemSom.doc & $\begin{array}{c}03 / 08 / 2015 \\
13: 43: 17 \\
\end{array}$ & & Aceito \\
\hline Folha de Rosto & fr-CEP.pdf & $\begin{array}{c}03 / 08 / 2015 \\
14: 22: 44 \\
\end{array}$ & & Aceito \\
\hline Outros & termodecienciadapesquisa.pdf & $\begin{array}{c}07 / 08 / 2015 \\
00: 24: 44 \\
\end{array}$ & & Aceito \\
\hline $\begin{array}{l}\text { Informações Bàsicas } \\
\text { do Projeto }\end{array}$ & $\begin{array}{l}\text { PB_INFORMAÇOCES_BÁSICAS_DO_P } \\
\text { ROJETO 511763.pdf }\end{array}$ & $\begin{array}{c}07 / 08 / 2015 \\
00: 30: 21 \\
\end{array}$ & & Aceito \\
\hline $\begin{array}{l}\text { Projeto Detalhado / } \\
\text { Brochura } \\
\text { Investigador }\end{array}$ & PPGSC_mest_prof.docx & $\begin{array}{c}02 / 09 / 2015 \\
22: 39: 28\end{array}$ & $\begin{array}{l}\text { Joao Paulo } \\
\text { Fernandes da Silva }\end{array}$ & Aceito \\
\hline Outros & ceppendencias0001.pdf & $\begin{array}{c}02 / 09 / 2015 \\
22: 42: 19 \\
\end{array}$ & $\begin{array}{l}\text { Joao Paulo } \\
\text { Fernandes da Silva }\end{array}$ & Aceito \\
\hline $\begin{array}{l}\text { Informaçōes Básicas } \\
\text { do Projeto }\end{array}$ & $\begin{array}{l}\text { PB_INFORMAÇŐES_BÁSICAS_DO_P } \\
\text { ROJETO 511763.pdf }\end{array}$ & $\begin{array}{c}02 / 09 / 2015 \\
22: 43: 06 \\
\end{array}$ & & Aceito \\
\hline
\end{tabular}

Endereço: Faculdade de Ciẻncias da Saúde - Campus Darcy Ribeiro

Bairro: Asa Norte CEP: 70.910-900

Municipio: BRASILIA

Telefone: (61)3107-1947

E-mail: cepfsunb@gmail.com 


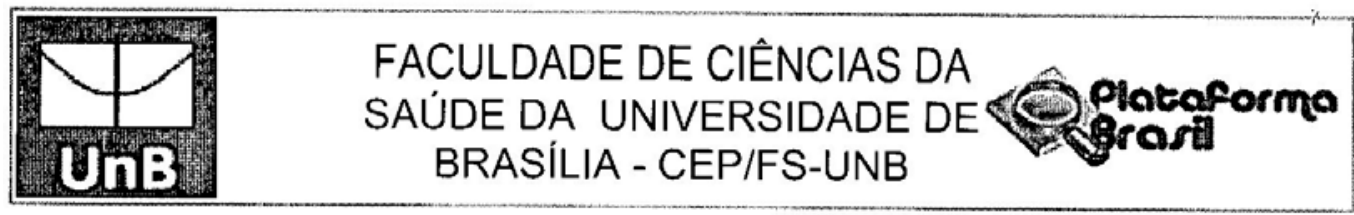

Continuaçāo do Parecer: 1.227.446

Situação do Parecer:

Aprovado

Necessita Apreciação da CONEP:

Não

BRASILIA, 14 de Setembro de 2015

Assinado por:

Marie Togashi

(Coordenador)

Endereço: Faculdade de Cie̊ncias da Saúde - Campus Darcy Ribeiro

Bairro: Asa Norte CEP: $70.910-900$

UF: DF

Municipio: BRASILIA

E-mail: cepfsunb@gmail.com

Pégina $O B$ de $O B$ 


\section{Apêndice 2}

\section{Termo de Consentimento Livre e Esclarecido - TCLE}

O(a) Senhor(a) está sendo convidado(a) a participar da pesquisa "Programa De Inclusão Digital Dos Conselheiros de Saúde: O uso das Tecnologias de Informação e Comunicação Auxiliam para o Controle Social?". O objetivo deste levantamento é Analisar a contribuição do Programa de Inclusão Digital dos Conselheiros de Saúde no que tange a apropriação do uso de tecnologias de informação e comunicação para o controle e participação social.

$\mathrm{O}$ (a) Senhor(a) receberá todos os esclarecimentos necessários antes e no decorrer deste procedimento e lhe asseguramos que seu nome não aparecerá sendo mantido o mais rigoroso sigilo através da omissão total de quaisquer informações que permitam identificá-lo(a).

A sua participação será através de um questionário semiestruturado que o(a) Senhor(a) deverá responder conforme sua facilidade de acesso, seja por meio eletrônico ou impresso. O procedimento tem um tempo estimado para sua realização previsto em, no máximo, 30 minutos.

Os riscos decorrentes de sua participação na pesquisa são relacionados a possíveis constrangimentos, nesse caso, o(a) Senhor(a) pode se recusar a responder (ou participar de qualquer procedimento) qualquer questão que lhe traga constrangimento, podendo desistir de participar da pesquisa em qualquer momento sem nenhum prejuízo para o(a) Senhor(a).

Se você aceitar participar, estará contribuindo para o melhor entendimento quanto aos processos de informação, educação e comunicação no âmbito das políticas de saúde em ambos os países envolvidos, bem como para reformulação de propostas inovadoras neste sentido.

Sua participação é voluntária, isto é, não há pagamento por sua colaboração. Todas as despesas que você tiver relacionadas diretamente ao projeto de pesquisa (passagem para o local da pesquisa, alimentação no local da pesquisa ou exames para realização da pesquisa) serão cobertas pelo pesquisador responsável.

Caso haja algum dano direto ou indireto decorrente de sua participação na pesquisa, você poderá ser indenizado, obedecendo-se as disposições legais vigentes no Brasil.

Os resultados serão divulgados pela Universidade de Brasília - UnB, podendo ser publicados posteriormente. Os dados e materiais utilizados ficarão sobre a guarda das pesquisadoras responsáveis.

Se o(a) Senhor(a) tiver qualquer dúvida em relação à este levantamento, por favor, entrar em contato com o pesquisador João Paulo Fernandes, em horário 
comercial, no período de 8 às 12h e das 14 às 18h, pelo telefone (61) 9112-3790, ou pelo e-mail jpaulofs@gmail.com.

Este projeto foi Aprovado pelo Comitê de Ética em Pesquisa da Faculdade de Ciências da Saúde (CEP/FS) da Universidade de Brasília. O CEP é composto por profissionais de diferentes áreas cuja função é defender os interesses dos participantes da pesquisa em sua integridade e dignidade e contribuir no desenvolvimento da pesquisa dentro de padrões éticos. As dúvidas com relação à assinatura do TCLE ou os direitos do participante da pesquisa podem ser obtidos através do telefone: (61) 31071947 ou do e-mail cepfs@unb.br ou cepfsunb@gmail.com, horário de atendimento de 10:00h às 12:00h e de 13:30h às 15:30h, de segunda a sexta-feira.

Este documento foi elaborado em duas vias, uma ficará com o pesquisador responsável e a outra com o Senhor(a).

Nome / Assinatura

Nome / Assinatura do(a) pesquisador(a) responsável

de

de 


\section{Apêndice 3}

\section{TERMO DE AUTORIZAÇÃO PARA UTILIZAÇÃO DE IMAGEM E SOM DE}

VOZ PARA FINS DE PESQUISA

$\mathrm{Eu}$, autorizo a utilização da minha imagem e som de voz, na qualidade de participante/entrevistado(a) da pesquisa intitulada "PROGRAMA DE INCLUSÃO DIGITAL DOS CONSELHEIROS DE SAÚDE: O USO DAS TECNOLOGIAS DE INFORMAÇÃO E COMUNICAÇÃO AUXILIAM O CONTROLE SOCIAL?" sob responsabilidade o pesquisador João Paulo Fernandes da Silva vinculada à Universidade de Brasília/ Faculdade de Ciências da Saúde.

Minha imagem e som de voz podem ser utilizadas apenas para análise por parte da equipe de pesquisa, apresentações em conferências profissionais e/ou acadêmicas, e em atividades educacionais.

Tenho ciência também de que a guarda e demais procedimentos de segurança com relação às imagens e sons de voz são de responsabilidade do(a) pesquisador(a) responsável.

Deste modo, declaro que autorizo, livre e espontaneamente, o uso para fins de pesquisa, nos termos acima descritos, da minha imagem e som de voz.

Este documento foi elaborado em duas vias, uma ficará com o(a) pesquisador(a) responsável pela pesquisa e a outra com o(a) participante. 


\section{Apêndice 4}

\section{INSTRUMENTO DE COLETA}

PERFIL SOCIODEMOGRÁFICO DO CONSELHO

\begin{tabular}{|l|l|l|}
\hline 1 & REGIÃO & \\
\hline 2 & ESTADO & \\
\hline 3 & MUNICÍPIO & \\
\hline 4 & POPULAÇÃO & \\
\hline 5 & PIB & \\
\hline 6 & IDH & \\
\hline
\end{tabular}

IDENTIFICAÇÃO DO CONSELHO

\begin{tabular}{|l|l|l|}
8 & ENDEREÇO & \\
\hline 9 & TELEFONE & \\
\hline 10 & EMAIL CONTATO & \\
11 & DATA DE CRIAÇÃO & \\
\hline
\end{tabular}

PERFIL DO RESPONDENTE

\begin{tabular}{|c|c|c|}
\hline 12 & NOME & \\
\hline 13 & EMAIL & \\
\hline 14 & SEXO & $\begin{array}{l}\text { [ }] \text { 1-Feminino } \\
\text { [ ] 2-Masculino }\end{array}$ \\
\hline 15 & IDADE & \\
\hline 16 & GRAU DE INSTRUÇÃO & 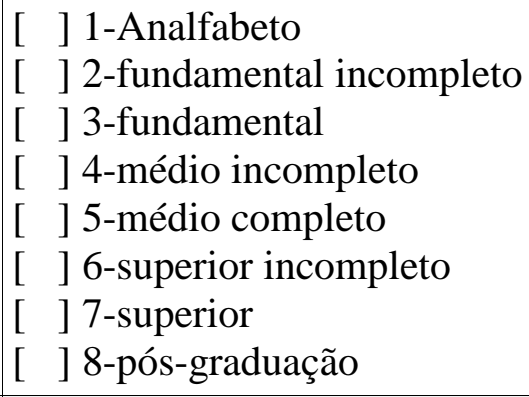 \\
\hline 17 & $\begin{array}{l}\text { SE SUPERIOR OU PÓS } \\
\text { GRADUADO, QUAL A } \\
\text { FORMAÇÃO? }\end{array}$ & \\
\hline 18 & $\begin{array}{l}\text { O(A) SENHOR(A) É } \\
\text { CONSELHEIRO(A) DE SAÚDE: }\end{array}$ & $\begin{array}{l}{[\text { ] } 1 \text { 1-nacional }} \\
{[\text { ] 2-estadual }} \\
{[\text { ] 3-municipal }} \\
{[\text { ] outro: }}\end{array}$ \\
\hline 19 & QUANTO TEMPO O(A) & \\
\hline
\end{tabular}




\begin{tabular}{|c|c|c|}
\hline & $\begin{array}{l}\text { SENHOR(A) ESTÁ NO CONSELHO } \\
\text { COMO CONSELHEIRO(A)? }\end{array}$ & \\
\hline 20 & $\begin{array}{l}\text { QUE SEGMENTO O(A) } \\
\text { SENHOR(A) REPRESENTA NO } \\
\text { CONSELHO? }\end{array}$ & 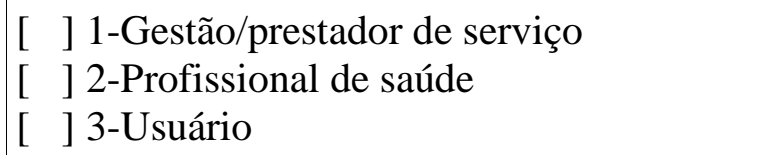 \\
\hline 21 & $\begin{array}{l}\text { O(A) SENHOR(A) CONHECE } \\
\text { OU JÁ OUVIU FALAR DO PID } \\
\text { (PROGRAMA DE INCLUSÃO } \\
\text { DIGITAL DOS CONSELHOS DE } \\
\text { SAÚDE) }\end{array}$ & $\begin{array}{l}\text { [ ] 1-Conheço } \\
\text { [ ] 2-Já ouvi falar/Li sobre o assunto } \\
\text { [ ] 3-Não }\end{array}$ \\
\hline 22 & $\begin{array}{l}\text { QUAIS DESTES } \\
\text { EQUIPAMENTOS POSSUI } \\
\text { ACESSO DIARIAMENTE? }\end{array}$ & 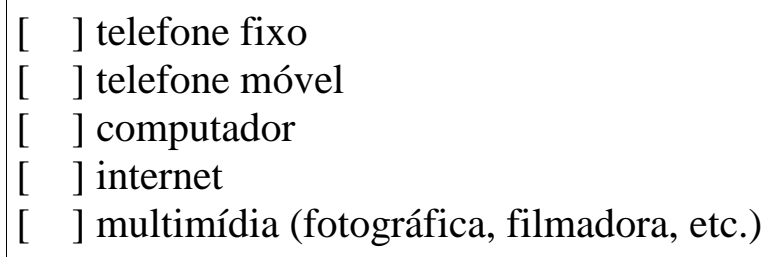 \\
\hline 23 & $\begin{array}{l}\text { QUAIS DESTES } \\
\text { EQUIPAMENTOS VOCE } \\
\text { POSSUI (particulares) }\end{array}$ & 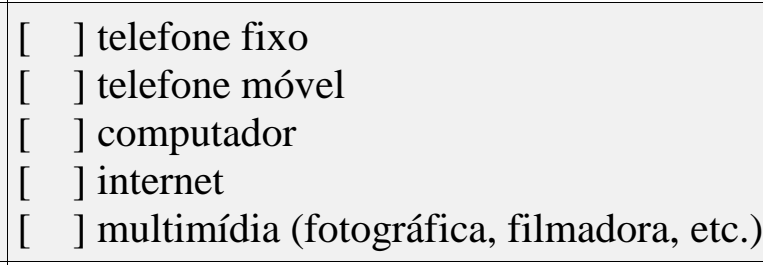 \\
\hline 24 & $\begin{array}{l}\text { QUAIS AS ATIVIDADES NA } \\
\text { ÁREA DE TECNOLOGIA O(A) } \\
\text { SENHOR(A) SE SENTE } \\
\text { APTO(A) A REALIZAR }\end{array}$ & 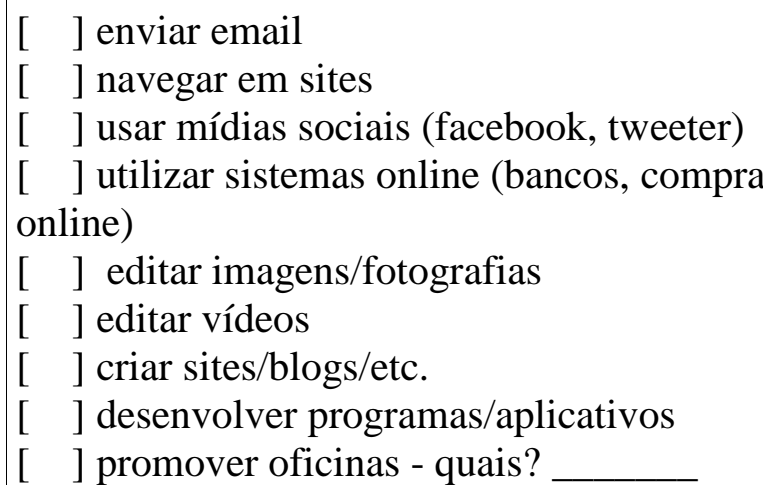 \\
\hline
\end{tabular}

CARACTERIZAÇÃO DO PROGRAMA DE INCLUSÃO DIGITAL DO CONSELHO

\begin{tabular}{|c|c|c|}
\hline 26 & $\begin{array}{l}\text { DOS EQUIPAMENTOS } \\
\text { RECEBIDOS PELO CONSELHO, } \\
\text { QUAIS ESTÃO FUNCIONANDO } \\
\text { PLENAMENTE? }\end{array}$ & $\begin{array}{ll}{[} & ] \text { computador } \\
{[} & ] \text { impressora } \\
{[} & ] \text { aparelho de TV } \\
{[} & ] \text { antena parabólica com decodificador } \\
{[} & ] \text { pacote de canais - TV por assinatura } \\
{[} & ] \text { conexão } \\
{[} & ] \text { outros }\end{array}$ \\
\hline 27 & $\begin{array}{l}\text { COMO O(A) SENHOR(A) FAZ } \\
\text { USO DESSES EQUIPAMENTOS? }\end{array}$ & \\
\hline 28 & $\begin{array}{l}\text { EM SUA OPINIÃO, COMO O(A) } \\
\text { SENHOR(A) QUALIFICA OS } \\
\text { EQUIPAMENTOS } \\
\text { RECEBIDOS/INSTALADOS? }\end{array}$ & $\begin{array}{l}\text { [ ] MUITO BOM } \\
\text { [ ] BOM } \\
\text { [ ] RUIM } \\
\text { [ ] MUITO RUIM }\end{array}$ \\
\hline
\end{tabular}




\begin{tabular}{|l|l|l|}
\hline 29 & A INTERNET FORNECIDA PARA O & {$[$ ] muito bom } \\
& CONSELHO EM SUA OPINIÃO É: & {$[$ ] bom } \\
& {$\left[\begin{array}{l}\text { ] ruim } \\
\end{array}\right.$} & {$\left[\begin{array}{l}\text { ] muito ruim } \\
\end{array}\right.$} \\
& {$[$ ] conselho não possui/recebeu internet } \\
\hline
\end{tabular}

SOBRE FORMAÇÃO

\begin{tabular}{|c|c|c|}
\hline 30 & $\begin{array}{l}\text { O(A) SENHOR(A) PARTICIPOU } \\
\text { DO CURSO DE FORMAÇÃO } \\
\text { PARA CONSELHEIROS DE } \\
\text { SAÚDE REALIZADO PELO } \\
\text { DEPARTAMENTO DE } \\
\text { INFORMÁTICA DO SUS } \\
\text { (DATASUS)? }\end{array}$ & {$\left[\begin{array}{ll}{[} & ] \text { 1-sim } \\
{[} & \text { ] 2-não }\end{array}\right.$} \\
\hline 31 & SE NÃO, POR QUÊ? & \\
\hline 32 & $\begin{array}{l}\text { ALÉM DO CURSO DO DATASUS O } \\
\text { SENHOR(A) PARTICIPOU DE } \\
\text { ALGUM CURSO DE FORMAÇÃO } \\
\text { VOLTADO PARA USO DESTES } \\
\text { EQUIPAMENTOS ENTREGUES } \\
\text { PELO PID? }\end{array}$ & {$\left[\begin{array}{ll}{[} & ] 1-\operatorname{sim} \\
{[} & ] 2-n a ̃ o\end{array}\right.$} \\
\hline 33 & $\begin{array}{l}\text { SOBRE O CURSO MINISTRADO } \\
\text { PELO DATASUS COMO O } \\
\text { SENHOR(A)AVALIA OS } \\
\text { SEGUINTES ASPECTOS (Apenas se } \\
\text { estiver participado do curso) }\end{array}$ & $\begin{array}{l}\text { Professores } \\
\text { [ ] muito bom } \\
\text { [ ] bom } \\
\text { [ ] ruim } \\
\text { [ ] muito ruim } \\
\text { conteúdo } \\
\text { [ ] muito bom } \\
\text { [ ] bom } \\
\text { [ ] ruim } \\
\text { [ ] muito ruim } \\
\text { metodologia } \\
\text { [ ] muito bom } \\
\text { [ ] bom } \\
\text { [ ] ruim } \\
\text { [ ] muito ruim } \\
\text { duração } \\
\text { [ ] muito bom } \\
\text { [ ] bom } \\
\text { [ ] ruim } \\
\text { [ ] muito ruim }\end{array}$ \\
\hline
\end{tabular}




\begin{tabular}{|c|c|c|}
\hline & & $\begin{array}{l}\text { organização } \\
\text { [ ] muito bom } \\
\text { [ ] bom } \\
\text { [ ] ruim } \\
\text { [ ] muito ruim } \\
\text { interação com o grupo } \\
\text { [ ] muito bom } \\
\text { [ ] bom } \\
\text { [ ] ruim } \\
\text { [ ] muito ruim } \\
\text { desenvolvimento pessoal } \\
\text { [ ] muito bom } \\
\text { [ ] bom } \\
\text { [ ] ruim } \\
\text { [ ] muito ruim } \\
\text { material didático } \\
\text { [ ] muito bom } \\
\text { [ ] bom } \\
\text { [ ] ruim } \\
\text { [ ] muito ruim }\end{array}$ \\
\hline 34 & $\begin{array}{l}\text { QUE TIPO DE CONHECIMENTO O } \\
\text { CURSO DE FORMAÇÃO DO } \\
\text { DATASUS LHE AGREGOU, PARA } \\
\text { ALÉM DOS QUE O SENHOR(A) JÁ } \\
\text { TINHA, NO USO DAS } \\
\text { TECNOLOGIAS DE INFORMAÇÃO } \\
\text { E COMUNICAÇÃO? } \\
\text { Para quem não fez o curso do } \\
\text { DATASUS } \\
\text { QUE TIPO DE CONHECIMENTO O } \\
\text { PID LHE AGREGOU, PARA ALÉM } \\
\text { DOS QUE O SENHOR(A) JÁ } \\
\text { TINHA, NO USO DAS } \\
\text { TECNOLOGIAS DE INFORMAÇÃO } \\
\text { E COMUNICAÇÃO? }\end{array}$ & \\
\hline 35 & $\begin{array}{l}\text { DE QUE FORMA AS } \\
\text { TECNOLOGIAS DE INFORMAÇÃO } \\
\text { E COMUNICAÇÃO PODEM } \\
\text { FORTALECER AS AÇÕES DO } \\
\text { CONSELHO? }\end{array}$ & \\
\hline 36 & $\begin{array}{l}\text { O OBJETIVO PRINCIPAL DO } \\
\text { PID É CONTRIBUIR PARA QUE } \\
\text { OS CONSELHEIROS DE } \\
\text { SAÚDE SE APROPRIEM DE }\end{array}$ & \\
\hline
\end{tabular}




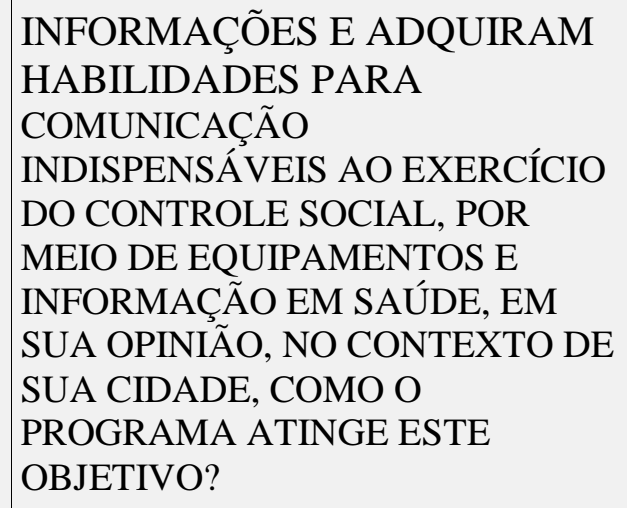

ESPAÇO DESTINADO PARA OBSERVAÇÕES FINAIS DA ENTREVISTA. 


\section{Apêndice 5}

\section{Comprovante de submissão do artigo}

\#1833 Sinopse

http://www.tempus.unb.br/index.php/tempus/author/submission/1833

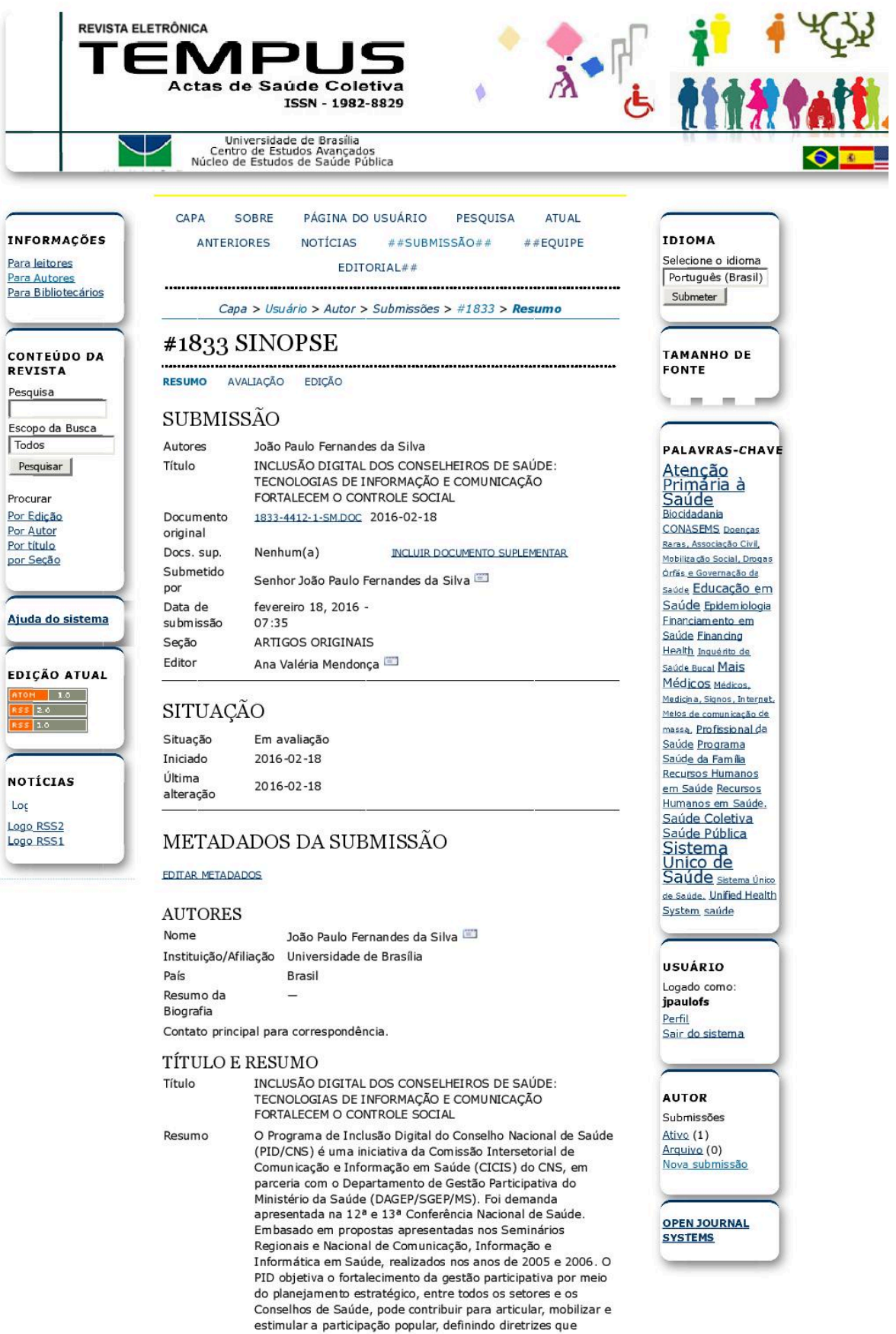




\section{Apêndice 6}

\section{Planilha dos discursos}

\begin{tabular}{|c|c|c|c|}
\hline $\begin{array}{l}\text { NATUREZA DO } \\
\text { OBJETIVO }\end{array}$ & $\begin{array}{l}\text { OBJETIVO DA } \\
\text { PERGUNTA - }\end{array}$ & PERGUNTA & IC/CATEGORIAS \\
\hline & $\begin{array}{l}\text { REGISTRAR O } \\
\text { CONHECIMENTO DOS } \\
\text { CONSELHEIROS EM } \\
\text { RELAÇÃO A } \\
\text { FORMAÇÃO DO } \\
\text { DATASUS }\end{array}$ & $\begin{array}{l}39 \text { - QUE TIPO DE } \\
\text { CONHECIMENTO O } \\
\text { CURSO DE } \\
\text { FORMAÇÃO DO } \\
\text { DATASUS LHE } \\
\text { AGREGOU, PARA } \\
\text { ALÉM DOS QUE O } \\
\text { SENHOR(A) JÁ TINHA, } \\
\text { NO USO DAS } \\
\text { TECNOLOGIAS DE } \\
\text { INFORMAÇÃO E } \\
\text { COMUNICAÇÃO? }\end{array}$ & $\begin{array}{l}\text {-NÃO SE APLICA } \\
\text { - AGREGOU } \\
\text { CONHECIMENTO NO } \\
\text { USO DAS TIC. } \\
\text {-EMPODERAMENTO } \\
\text {-MELHORA NO } \\
\text { DESEMPENHO DAS } \\
\text { AÇÕES DE } \\
\text { CONSELHEIRO. }\end{array}$ \\
\hline 蛋 & $\begin{array}{l}\text { IDENTIFICAR OS } \\
\text { MEIOS COMO } \\
\text { RECURSOS } \\
\text { TECNOLÓGICOS } \\
\text { UTILIZADOS NAS } \\
\text { AÇÕES DO CONSELHO }\end{array}$ & $\begin{array}{l}40 \text { - DE QUE FORMA } \\
\text { AS TECNOLOGIAS DE } \\
\text { INFORMAÇÃO E } \\
\text { COMUNICAÇÃO } \\
\text { PODEM FORTALECER } \\
\text { AS AÇÕES DO } \\
\text { CONSELHO? }\end{array}$ & $\begin{array}{l}\text {-NÃO SE APLICA } \\
\text {-FORTALECE AS } \\
\text { AÇÕES COTIDIANAS } \\
\text { DO } \\
\text { CONSELHO.(AÇÕES } \\
\text { INTERNAS) } \\
\text {-PROMOVE A } \\
\text { PARTICIPAÇÃO } \\
\text { SOCIAL } \\
\text {-FACILITA A } \\
\text { COMUNICAÇÃO. }\end{array}$ \\
\hline 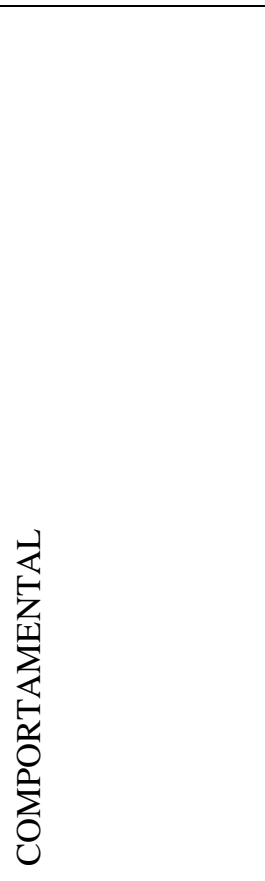 & $\begin{array}{l}\text { CONHECER A } \\
\text { PERCEPÇÃO DOS } \\
\text { CONSELHEIROS } \\
\text { QUANTO A } \\
\text { APROPRIAÇÃO DOS } \\
\text { OBJETIVOS DO PID E } \\
\text { SEU USO EM NÍVEL } \\
\text { LOCAL. }\end{array}$ & $\begin{array}{l}\text { O OBJETIVO } \\
\text { PRINCIPAL DO PID É } \\
\text { CONTRIBUIR PARA } \\
\text { QUE OS } \\
\text { CONSELHEIROS DE } \\
\text { SAÚDE SE APROPRIEM } \\
\text { DE INFORMAÇÕES E } \\
\text { ADQUIRAM } \\
\text { HABILIDADES PARA } \\
\text { COMUNICAÇÃO } \\
\text { INDISPENSÁVEIS AO } \\
\text { EXERCÍCIO DO } \\
\text { CONTROLE SOCIAL, } \\
\text { POR MEIO DE } \\
\text { EQUIPAMENTOS E } \\
\text { INFORMAÇÃO EM } \\
\text { SAÚDE, EM SUA } \\
\text { OPINIÃO, NO } \\
\text { CONTEXTO DE SUA } \\
\text { CIDADE, COMO O } \\
\text { PROGRAMA ATINGE } \\
\text { ESTE OBJETIVO? }\end{array}$ & $\begin{array}{l}\text { - O PID NÃO ATINGIU } \\
\text { OS OBJETIVOS. } \\
\text {-NÃO SE APLICA. } \\
\text {-O PID ATINGE OS } \\
\text { OBJETIVOS COM } \\
\text { RESSALVA } \\
\text {-O PID ATINGE O } \\
\text { OBJETIVO }\end{array}$ \\
\hline
\end{tabular}




\begin{tabular}{|l|l|l|l|}
\hline & REGISTRAR O & 42 - QUE TIPO DE & -NÃO SE APLICA \\
& CONHECIMENTO & CONHECIMENTO O & - O PID NÃO AGREGOU \\
& AGREGADO DO PID & PID LHE AGREGOU, & CONHECIMENTO. \\
& PARA OS & PARA ALÉM DOS QUE & -O PID AGREGOU \\
& CONSELHEIROS. & O SENHOR(A) JÁ & CONHECIMENTO \\
& & TINHA, NO USO DAS & \\
$\sum_{0}$ & & TECNOLOGIAS DE & \\
0 & & INFORMAÇÃO E & \\
\hline & & COMUNICAÇÃO? & \\
\hline
\end{tabular}




\section{Apêndice 7}

\section{Discursos}

Que tipo de conhecimento o curso de formação do DATASUS lhe agregou, para além dos que o senhor(a) já tinha, no uso das tecnologias de informação e comunicação?

\section{Categoria A - Agregou conhecimento no uso das TIC.}

Eu acredito que o curso colabora muito, somando o meu conhecimento teórico com o conhecimento prático dos técnicos do PID. Eu enriqueci muito minha formação para contribuir na formação dos outros Conselheiros. Eu não tinha nenhum conhecimento e me agregou muito, inclusive nos sites que eu não conhecia, como é fazer o e-mail, fazer essa parte de blog, facebook, foi muito legal. Facilitou o acesso a sites que são importantes em consultas para os conselheiros. Mas falta muito ainda, mas só o pouquinho que teve foi bom. Conseguimos avançar mais um pouco e deixar de ter medo de usar os equipamentos. A gente aprendeu bastante. Me auxiliou também na busca de sistemas que pudessem me fornecer informes sobre o relatório anual de gestão, planos de saúde, regiões de saúde, macro regiões de saúde, e outros sistemas. Para ser uma pessoa mais intelectual ao sistema que vivenciamos hoje com a tecnologia avançada, no aprimoramento para a utilização de abrir programas, usar os instrumentos para eu acessar algumas coisas em Brasília, enfim, foi de suma importância para mim.

\section{Categoria B - Não se aplica.}

Eu sou gestor da área de informática e necessariamente não precisava do curso. Eu poderia dizer para você o que é instrumentalizar tecnicamente o Conselheiro para que ele possa usar também essas ferramentas tecnológicas para ter mais informação e exercer melhor sua atribuição.

\section{Categoria C - Empoderamento.}

O curso me deu maior autonomia, e ainda o empoderamento do território. O curso me ajudou a descobrir o caminho das pedras e a conhecer locais onde posso buscar informações, empoderar para poder executar melhor o controle social. Buscar na mídia a questão dos conselhos, de formação, como os conselhos são formados, as leis. 
Enfim, não preciso pegar o livro, eu entro na mídia eu pesquiso proporcionando uma abertura para perder o medo de utilizar estas tecnologias.

\section{Categoria D - Melhora no desempenho das ações de conselheiro.}

Me agregou a ter um funcionamento melhor junto das discussões e das políticas públicas.

\section{Discurso do Sujeito Coletivo}

Eu acredito que o curso colabora muito, somando o meu conhecimento teórico com o conhecimento prático dos técnicos do PID. Eu enriqueci muito minha formação para contribuir na formação dos outros Conselheiros. Eu não tinha nenhum conhecimento e me agregou muito, inclusive nos sites que eu não conhecia, como é fazer o e-mail, fazer essa parte de blog, facebook, foi muito legal. Facilitou o acesso a sites que são importantes em consultas para os conselheiros. Mas falta muito ainda, mas só o pouquinho que teve foi bom. Conseguimos avançar mais um pouco e deixar de ter medo de usar os equipamentos. A gente aprendeu bastante. Me auxiliou também na busca de sistemas que pudessem me fornecer informes sobre o relatório anual de gestão, planos de saúde, regiões de saúde, macro regiões de saúde, e outros sistemas. Para ser uma pessoa mais intelectual ao sistema que vivenciamos hoje com a tecnologia avançada, no aprimoramento para a utilização de abrir programas, usar os instrumentos para eu acessar algumas coisas em Brasília, enfim, foi de suma importância para mim. Eu sou gestor da área de informática e necessariamente não precisava do curso. Eu poderia dizer para você o que é instrumentalizar tecnicamente o Conselheiro para que ele possa usar também essas ferramentas tecnológicas para ter mais informação e exercer melhor sua atribuição. O curso me deu maior autonomia, e ainda o empoderamento do território. O curso me ajudou a descobrir o caminho das pedras e a conhecer locais onde posso buscar informações, empoderar para poder executar melhor o controle social. Buscar na mídia a questão dos conselhos, de formação, como os conselhos são formados, as leis. Enfim, não preciso pegar o livro, eu entro na mídia eu pesquiso proporcionando uma abertura para perder o medo de utilizar estas tecnologias. Me agregou a ter um funcionamento melhor junto das discussões e das políticas públicas. 
Que tipo de conhecimento o PID lhe agregou, para além dos que o senhor(a) já tinha, no uso das tecnologias de informação e comunicação?

\section{A - Não se aplica}

Na medida em que não conheço o programa e que não participei de cursos, não posso avaliar o que foi agregado.

\section{B - O PID não agregou conhecimento}

Não surtiu o efeito que deveria, para o qual foi proposto. De que adianta ir para regiões fazer outras coisas se as pessoas não vão ter acesso à internet? Não tenho como falar o que me agregou porque eu não tenho participado diretamente do programa. Vivo a questão da tecnologia e informação independente do PID. O fato de ter ou não o PID, não mudou nada.

\section{C - O PID agregou conhecimento}

O PID trouxe todas as informações que são acompanhadas mensalmente pelas comissões do conselho, o que aproximou mais as informações e a realidade.

\section{Discurso do sujeito coletivo}

Não surtiu o efeito que deveria, para o qual foi proposto. Não tenho como falar o que me agregou porque eu não tenho participado diretamente dos benefícios do programa. Vivo a questão da tecnologia e informação independente do PID. O fato de ter ou não o programa, não mudou nada. Até trouxe informações que são acompanhadas mensalmente pelas comissões do conselho, o que aproximou mais as informações e a realidade, mas não adianta ir para regiões pra fazer outras coisas se as pessoas não há acesso à internet.

\section{0- DE QUE FORMA AS TECNOLOGIAS DE INFORMAÇÃO E COMUNICAÇÃO PODEM FORTALECER AS AÇÕES DO CONSELHO?}

\section{A - O uso das TIC fortalece as ações cotidianas do conselho.}

Tudo que se faz hoje dentro do conselho tem a participação de tecnologia. Desde um simples telefonema a um jornal, uma impressão, ou seja, por meio da tecnologia é que se pode desenvolver as ações, planejamentos, comunicação com outros conselhos e 
além disso, divulgar atividades. É importantíssimo que se tenha a tecnologia para facilitar pois acredito que nós precisamos interagir. Para isto, os equipamentos devem estar disponíveis para os conselheiros de modo a viabilizar a informação, pesquisa e reprodução de material.

\section{B - Não se aplica}

\section{C- Promove a participação social}

As tecnologias podem transformar para melhor uma sociedade, mais participativa não só na saúde.

\section{D - Facilita a comunicação}

As tecnologias tem o viés de aproximar e de oferecer oportunidade para que todos estejam antenados numa mesma sintonia. É Através dela que conseguimos ter agilidade na comunicação e informações que são enviadas aos municípios. Esse mecanismo facilita muito o trabalho quando necessário uma mobilização ou capacitação, regionalizada ou para o município. Comunicação é fundamental dentro de um conselho de saúde porém, as tecnologias precisam ser compreendidas pelos conselheiros, as possibilidades de comunicação via tecnologia da informação com reuniões virtuais, filmagens e usar toda a estrutura que existe instalada para divulgar as ações dos conselhos. Talvez a medida que a gente experimentar, poderemos ousar mais.

\section{E - O uso da TIC fortalece o controle social}

Nós temos informação chegando em tempo real para toda a sociedade. Para o controle social acaba sendo um elemento facilitador, podendo ajudar bastante o conselheiro de saúde a se expressar melhor e ter condições de exercer sua função. Por isso, cursos para os conselheiros são importantes, isso nos fortalece muito. Existem atribuições que ficam limitadas por conta da dificuldade técnica que o conselheiro tem, tanto em usar esses instrumentos como também na pouca oportunidade de cursos que são oferecidos nessa linha. A formação política é necessária mas a formação técnica também, pois agrega qualidade a atuação do conselho. Tecnologias podem agregar conhecimento, instrumentalizar e fiscalizar. Então é de fundamental importância que os 
conselheiros estejam procurando se informar, pois se o conselho não sabe buscar onde se gastam os recursos públicos, ele não pode atuar.

\section{Discurso do sujeito coletivo:}

Tudo que se faz hoje dentro do conselho tem a participação de tecnologia. Desde um simples telefonema a um jornal, uma impressão, ou seja, por meio da tecnologia é que se pode desenvolver as ações, planejamentos, comunicação com outros conselhos e além disso, divulgar atividades. É importantíssimo que se tenha tecnologia para facilitar, pois acredito que nós precisamos interagir. Para isto, os equipamentos devem estar disponíveis para os conselheiros de modo a viabilizar a informação, pesquisa e reprodução de material. As tecnologias podem transformar para melhor uma sociedade, mais participativa não só na saúde, com o viés de aproximar e de oferecer oportunidade para que todos estejam antenados numa mesma sintonia. É Através dela que conseguimos ter agilidade na comunicação e informações que são enviadas aos municípios com mecanismos que facilitam muito o trabalho quando necessário uma mobilização ou capacitação, regionalizada ou para o município. Comunicação é fundamental dentro de um conselho de saúde porém, as tecnologias precisam ser compreendidas pelos conselheiros quanto as possibilidades de comunicação via tecnologia da informação com reuniões virtuais, filmagens e uso de toda a estrutura que existe instalada. Talvez a medida em que fomos experimentando, poderemos ousar mais. Nós temos informação chegando em tempo real para toda a sociedade. Para o controle social acaba sendo um elemento facilitador, podendo ajudar o conselheiro de saúde a se expressar melhor e ter condições de exercer sua função. Por isso, cursos para os conselheiros são importantes, isso nos fortalece muito. Existem atribuições que ficam limitadas por conta de dificuldades técnicas que o conselheiro tem, tanto no uso desses instrumentos como também na pouca oportunidade de cursos que são oferecidos nessa linha. A formação política é necessária mas a formação técnica também, pois agrega qualidade a atuação do conselho.

41 - O objetivo principal do PID é contribuir para que os conselheiros de saúde se apropriem de informações e adquiram habilidades para comunicação indispensáveis ao exercício do controle social, por meio de equipamentos e informação em saúde. Em sua opinião, no contexto de sua cidade, como o programa atinge este objetivo? 


\section{A- O PID não atingiu o objetivo}

O objetivo do programa não foi atingido e nem foi alcançado na sua integralidade. O PID tem uma concepção ampla que o controle social não se apropriou ficando muito na entrega de equipamentos e no monitoramento desses. É preciso um planejamento no conselho para que isso venha a acontecer, do contrário o programa vai ficar como mais um produto colocado sem a devida utilização. Então falta política, falta foco dos próprios conselhos e dos próprios gestores para que o PID possa atingir esse objetivo. Dificuldades como a não aquisição e até mesmo de não haver um local próprio para uso, com infraestrutura básica, faz com que os equipamentos sejam deslocados para outros locais. Precisamos combater isso de todas as formas, para que os equipamentos estejam sempre a disposição dos conselheiros. Melhor se tivesse existido uma formação para os conselheiros, o que não se efetivou muito. O PID foi um grande esforço, mas não consigo ver resultados concretos que possam impactar na cidade como um veículo de divulgar informação, porque a gente usa muito pouco.

\section{B - Não se aplica}

Eu trocaria a palavra controle social por participação social que esse trabalho deu porque ele foi além da saúde. Quando ele não conseguiu organizar o conselho, organizou a escola do bairro, ele conseguiu minimizar a agressão daquela região, daquele território, então foi muito bom. Pena que a gente não conseguiu fazer com que essa resposta fosse coletiva. Defendo esse programa no sentido da gente buscar avançar o controle social e ter a maior proximidade daqueles que estão no dia a dia do controle social com a sociedade, e também haver uma interlocução, uma interação interconceitos. De qualquer forma vou ficar devendo, porque eu só tenho ouvido falar do PID, inclusive eu não conheço o documento.

\section{C- O PID atinge o objetivo com ressalvas}

Eu acredito que atinge o objetivo, mas não como os diretores, os coordenadores do PID nacional pensem. É preciso ainda melhorar. Devemos entender que existem ribeirinhos, indígenas, quilombolas, idosos dentro desses conselhos, então é preciso que haja um sistema que dê acesso diretamente a informação, que englobe todas elas, pois o que mais vejo é o retalhamento das informações. O programa empodera, passa confiança, tira inclusive um pouco do medo. Existe uma certa insegurança na maioria de 
nós, contudo o curso chega para mostrar que é possível a gente entra de cabeça e poder com isso tirar todo o proveito necessário para a melhoria, para a qualificação da atuação dos conselheiros, mas isso é algo insuficiente ainda. A gente poderia estar muito melhor se os gestores deixassem os conselhos trabalharem. Em alguns municípios, a maioria dos equipamentos não estão disponíveis para o conselho e, onde foram disponibilizadas salas para os equipamentos, temos o controle social muito melhor, mais fortalecido. Era para ter sido feita uma capacitação, porém a única coisa que a gente tem feito é repassar as informações que o Ministério manda.

\section{D - O PID atinge o objetivo}

O PID foi a grande sacada do governo federal em relação ao controle social. Nós tínhamos conselheiros que não sabiam nem ligar um computador, hoje navegam na rede, interagem conosco, fazem perguntas e pesquisam, o que possibilita o acesso a informação e, consequentemente, o controle social fica mais fortalecido. Houve um lapso de tempo entre entrega do equipamento e a capacitação, poderia ter sido um pouco mais dinâmico. Nos deu abertura porque as pessoas podem utilizar este instrumento na própria secretaria do conselho. Eu acho que veio beneficiar, pois transformamos o que recebemos, de âmbito nacional, em informações para o município.

\section{Discurso do sujeito coletivo}

Eu acredito que atinge o objetivo, mas não como os diretores, os coordenadores do PID nacional pensam. É preciso ainda melhorar. Devemos entender que existem ribeirinhos, indígenas, quilombolas, idosos dentro desses conselhos, então é preciso que haja um sistema que dê acesso diretamente a informação, que englobe todas elas, pois o que mais vejo é o retalhamento das informações. O programa empodera, passa confiança, tira inclusive um pouco do medo. Existe uma certa insegurança na maioria de nós, contudo o curso chega para mostrar que é possível a gente entrar de cabeça e poder com isso tirar todo o proveito necessário para a melhoria, para a qualificação da atuação dos conselheiros, mas isso é algo insuficiente ainda. A gente poderia estar muito melhor se os gestores deixassem os conselhos trabalharem. Em alguns municípios, a maioria dos equipamentos não estão disponíveis e, onde foram disponibilizadas salas para os equipamentos, temos o controle social muito melhor, mais fortalecido. Era para ter sido feita uma capacitação, porém a única coisa que a gente tem feito é repassar as informações que o Ministério manda. Eu trocaria a palavra controle social por 
participação social porque ele foi além da saúde. Quando ele (PID) não conseguiu organizar o conselho, organizou a escola do bairro, conseguiu minimizar a agressão daquela região, daquele território, então foi muito bom. Pena que a gente não conseguiu fazer com que essa resposta fosse coletiva. Defendo esse programa no sentido da gente buscar avançar o controle social e ter maior proximidade daqueles que estão no dia a dia com a sociedade, e também haver uma interlocução, uma interação interconceitos. No entanto, o PID tem uma concepção ampla que o controle social não se apropriou ficando muito na entrega de equipamentos e no monitoramento desses. É preciso um planejamento no conselho para que isso venha a acontecer, do contrário o programa vai ficar como mais um produto colocado sem a devida utilização. Então falta política, falta foco dos próprios conselhos e dos próprios gestores para que o PID possa atingir esse objetivo. Dificuldades como a não aquisição e até mesmo de não haver um local próprio para uso, com infraestrutura básica, faz com que os equipamentos sejam deslocados para outros locais. Precisamos combater isso de todas as formas, para que os equipamentos estejam sempre a disposição dos conselheiros. O PID foi a grande sacada do Governo Federal em relação ao controle social. Nós tínhamos conselheiros que não sabiam nem ligar um computador, hoje navegam na rede, interagem conosco, fazem perguntas e pesquisam, o que possibilita o acesso à informação e, consequentemente, o controle social fica mais fortalecido. Houve um lapso de tempo entre entrega do equipamento e a capacitação, poderia ter sido um pouco mais dinâmico. Nos deu abertura porque as pessoas podem utilizar este instrumento na própria secretaria do conselho. Eu acho que veio beneficiar, pois transformamos o que recebemos, de âmbito nacional, em informações para o município. 